\title{
DEBTS AND DEFICITS IN AUSTRALIA
}

\author{
by \\ Larry Sjaastad \\ The University of Chicago \\ and \\ The University of Western Australia
}

DISCUSSION PAPER 90.08

JUNE 1990 
DEBTS AND DEFICITS IN AUSTRALIA

by

Larry sjaastad

The University of Chicago

and

The University of Western Australia

Discussion Paper 90.08

June 1990

ISSN $0811-6007$

ISBN $0-86422-765-5$ 


\author{
ABSTRACT OF \\ DEBTS AND DEFICITS IN AUSTRALIA \\ by \\ Larry A. Sjaastad \\ The University of Chicago
}

The question of the current account deficit and the external debt has led to a spirited and, at times, hysterical controversy in Australia over the past year and a half. One of the more intriguing aspects of the Australian current account deficit and external debt "problem" is the fact that both have emerged during a period in which a large fiscal deficit has been transformed into a substantial surplus, and consumption (saving) as a fraction of GDP has declined (risen) two percentage points. Neo-Ricardians may take comfort from the fact that nearly half of the implied increase in public-sector saving has been offset by a decline in household saving, which fell from 6.7 per cent of GDP in $1984 / 85$ to 5.1 per cent in $1987 / 88$. The Australian case is not the typical text-book case in which in which a current account deficit is accompanied by (and readily attributed to) a fiscal deficit.

The enormous increase in Australian interest rates from about 10 per cent (money market) in early 1988 to about 18 per cent in late 1989 has further fueled the debate. It is widely believed in Australia that this very large increase in interest rates since 1988 is due to the current account deficit and the external debt. The paper is mainly addressed to that issue. The basic hypothesis is that Australian interest rates are "high" because the market is anticipating a depreciation of the Australian dollar (i.e., the "peso" problem).

The first half of the paper involves the development and testing of a "Law of One Price" model for the Australian price level, and that model 
performs well empirically. The results indicate that, despite her splendid geographic isolation, Australia is not at all insulated from shocks arising from external inflation and movements in third-country exchange rates. The effects of world inflation and third-country exchange rate instability are, however, almost immediately neutralized by the mechanics of the Australian exchange rate, particularly so since the exchange rate was floated in late 1983. The evidence indicates that for the entire $1972-89$ period, purchasing power parity held quite well; however, the evidence does not support that proposition for either of two sub periods (1972-83 and 1984-89). Finally, there is quite strong evidence that the Australian dollar became increasing over valued (in markets for goods, of course) during the second half of 1988, and early 1989 by as much as 5 to 9 percent, which provides a plausible explanation for the high level of the domestic real rate of interest during 1989 .

The study also investigates the relationship between the current account of the balance of payments, on the one hand, and the multilateral "real" exchange rate and the real rate of interest, on the other. Evidence consistent with the proposition that a current account deficit leads a decline in the "real" exchange rate was not found. However, both a current account deficit and interest payments on external debt tend to increase the real rate of interest. These considerations, however, explain only a small part of the increase in the real rate of interest that has actually occurred. It appears quite likely, then, that the rise in interest rates during late 1988 and early 1989 was due to anticipation of a significant real depreciation of the Australian dollar. 


\title{
DEBTS AND DEFICITS IN AUSTRALIA*
}

\author{
by \\ Larry A. Sjaastad \\ The University of Chicago
}

\section{INTRODUCTION}

The question of the current account deficit and the external debt has become the hottest issue in Australia since the "Bottom of the Harbor" scandal of 1982 . The net external debt, currently calculated at a bit more than 30 per cent of GDP (with interest payments at about 3 per cent of GDP), is growing rapidly due to a current account deficit that, in the second half of 1989, is approximately 5 per cent of GDP. The spirited and, at times, hysterical controversy over the debt and deficit issue has been lead by Professor John Pitchford, who supports (or at least gives comfort to) the Labor government's policy of benign neglect of the deficit, arguing quite sensibly that foreign borrowing is not inherently bad in the absence of externalities that cause the private cost of external borrowing to fall short of the social cost. ${ }^{1}$ The financial press and, more recently, the business community, have strongly condemned the government's attitude.

One of the more intriguing aspects of the Australian current account deficit and external debt "problem" is the fact that both have emerged during a period in which a large fiscal deficit has been transformed into a

*This is a revised version of a paper for the Fiscal Policy Conference hosted by the McGill Economics Centre, Montreal, December 6-8, 1989.

${ }^{1}$ See, for example, John Pitchford, "Does Australia Really Have a Current Account Problem?," in Policy, Winter 1989, published by the Center for Independent Policy Studies, Melbourne. 
substantial surplus, and consumption (saving) as a fraction of GDP has declined (risen) two percentage points. ${ }^{2}$ Neo-Ricardians may take comfort from the fact that nearly half of the implied increase in public-sector saving has been offset by a decline in household saving, which fell from 6.7 per cent of GDP in $1984 / 85$ to 5.1 per cent in $1987 / 88$. The major increase in spending has come from a surge in investment during 1986/88 and more recently from housing construction. Thus the Australian case is not the typical one in which in which a current account deficit is accompanied by (and readily attributed to) a fiscal deficit.

The most recent development has been an enormous increase in interest rates on Australian dollar assets. During calendar year 1988, the average money market interest rate was 11.8 per cent; by early 1989 , it had risen to more than 15 per cent and in late 1989 stood at about 18 per cent. At the same time the prime lending rate was 20 per cent, which implies a real rate of interest well in excess of 10 per cent.

Quarterly data in inflation, interest, and exchange rates for the 1981-89 period are presented in Table 1. The columns titled "Prices" and "Wages" are the percentage changes from the same quarter a year earlier in the Australian Consumer Price Index (ACPI) and the wage index, respectively. ${ }^{3}$ The nominal interest rate is an average of the monthly observations on money-market interest rates as reported in the Bulletin of the Reserve Bank of Australia, and the real rate of interest is the nominal

\footnotetext{
${ }^{2}$ The Australian fiscal year runs from July to June. During 1984/85, the fiscal deficit was 3.17 per cent of GDP; by $1987 / 88$ the fiscal surplus had risen to 0.70 per cent of GDP and is currently much larger. In the same period, consumption fell from 60.0 to 58.2 per cent of GDP.

${ }^{3}$ The wage index in Table 1 , and which is used later in the regressions, is based on average weekly earnings of males and is compiled by the Australian Bureau of Statistics (ABS).
} 
TABLE 1

INFLATION, INTEREST AND EXCHANGE RATES, AUSTRALIA: 1984-89 ${ }^{\mathrm{A}}$

(In per cent, at annual rates)

\begin{tabular}{|c|c|c|c|c|c|}
\hline \multirow[b]{2}{*}{ Quarter } & \multicolumn{2}{|c|}{ Inflation } & \multicolumn{2}{|c|}{ Interest Rates } & \multirow{2}{*}{$\begin{array}{c}\text { Exchange } \\
\text { Rate }\end{array}$} \\
\hline & Prices & Wages & Nominal. & Real & \\
\hline $1981: 1$ & 9.13 & 12.32 & 10.36 & 0.75 & -5.89 \\
\hline $1981: 2$ & 8.65 & 12.95 & 12.27 & 3.03 & -1.71 \\
\hline $1981: 3$ & 8.83 & 10.81 & 13.12 & 2.57 & 1.63 \\
\hline $1981: 4$ & 9.68 & 8.60 & 12.74 & 2.82 & 2.44 \\
\hline $1982: 1$ & 9.01 & 11.11 & 13.84 & 5.14 & 7.23 \\
\hline $1982: 2$ & 9.08 & 10.63 & 15.78 & 3.79 & 8.79 \\
\hline $1982: 3$ & 10.24 & 10.67 & 13.79 & 1.53 & 15.05 \\
\hline $1982: 4$ & 9.92 & 12.26 & 12.19 & 2.37 & 18.24 \\
\hline 1983: 1 & 10.30 & 8.81 & 10.13 & 1.47 & 14.00 \\
\hline 1983:2 & 10.05 & 6.06 & 10.84 & 2.85 & 18.13 \\
\hline $1983: 3$ & 8.50 & 5.62 & 9.71 & 1.46 & 11.04 \\
\hline $1983: 4$ & 8.16 & 6.81 & 7.31 & 0.43 & 4.36 \\
\hline $1984: 1$ & 7.18 & 8.09 & 9.00 & 4.76 & 1.51 \\
\hline 1984: 2 & 5.99 & 11.18 & 12.70 & 7.56 & -3.33 \\
\hline $1984: 3$ & 5.73 & 9.90 & 10.85 & 5.08 & 4.96 \\
\hline $1984: 4$ & 4.71 & 7.32 & 10.79 & 4.99 & 7.38 \\
\hline 1985: 1 & 5.09 & 5.77 & 11.76 & 3.63 & 21.40 \\
\hline 1985: 2 & 6.56 & 3.42 & 14.78 & 5.00 & 30.45 \\
\hline $1985: 3$ & 7.28 & 4.32 & 15.23 & 6.19 & 18.29 \\
\hline $1985: 4$ & 8.02 & 6.07 & 17.03 & 7.58 & 20.74 \\
\hline 1986: 1 & 8.85 & 7.33 & 17.74 & 9.34 & 6.87 \\
\hline $1986: 2$ & 7.94 & 6.88 & 13.52 & 4.79 & -6.71 \\
\hline $1986: 3$ & 8.38 & 8.11 & 15.66 & 4.55 & 11.56 \\
\hline $1986: 4$ & 8.95 & 7.50 & 16.08 & 6.32 & 5.97 \\
\hline $1987: 1$ & 8.57 & 5.27 & 16.03 & 8.59 & 4.42 \\
\hline $1987: 2$ & 8.55 & 5.98 & 13.65 & 6.77 & -0.17 \\
\hline $1987: 3$ & 7.66 & 4.62 & 11.87 & 4.79 & -13.88 \\
\hline $1987: 4$ & 6.69 & 5.54 & 10.68 & 3.84 & -8.35 \\
\hline $1988: 1$ & 6.41 & 6.88 & 10.27 & 3.32 & -6.98 \\
\hline $1988: 2$ & 6.63 & 6.90 & 11.12 & 3.46 & -8.63 \\
\hline $1988: 3$ & 6.88 & 5.59 & 12.35 & 3.68 & -11.27 \\
\hline $1988: 4$ & 7.41 & 6.53 & 13.86 & 7.67 & -17.58 \\
\hline $1989: 1$ & 6.47 & 6.88 & 15.38 & 8.42 & -16.37 \\
\hline $1989: 2$ & 7.26 & 7.18 & 16.79 & 7.03 & 0.12 \\
\hline
\end{tabular}

A. See text for sources and definitions. 
rate adjusted by inflation as measured by the ACPI. ${ }^{4}$ Finally, the "Exchange Rate" column is the change in the quarterly average of the exchange rate (the Australian dollar price of the U.S. dollar) over the same quarter a year earlier.

Taking into account the short-term nature of the inflation rates reported in. Table 1 , one is struck by the stability of the Australian inflation. Real interest rates have also been quite stable except during quarters when the inflation rate has been abnormally low or high. The large increase in the real rate that: began in 1988: 1 is almost entirely due to the dramatic increase in nominal rates that also began in that quarter. It is widely believed in Australia that this very large increase in interest rates since 1988 is due to the current account deficit and the external debt. The remainder of this paper addresses that issue. ${ }^{5}$

Most of the external debt of Australia is owed by the private sector ("official" debt is a mere 11 per cent of the total) and, although hard data are difficult to come by, it appears that much less than half of the net external debt is denominated in Australian dollars. Consequently, it is difficult to understand how the capital inflow (that finances the current account deficit) itself can be responsible for interest rates on assets denominated in Australian dollars to be more than double those on comparable assets denominated in U.S. dollars. Rather, one suspects that the behavior of the exchange rate is involved. As is evident from Table 1 , the exchange rate has been rather unstable and, since 1986, the Australian

\footnotetext{
${ }^{4}$ The inflation rate used to convert interest rates from nominal to real was defined as the change (at an annual rate) of the ACPI one quarter ahead over one quarter behind the quarter in question.

${ }^{5}$ Portions of the empirical work reported in the paper are drawn from L.A. Sjaastad, "Exchange Rates and Commodity Price: The Australian Case," (mimeo), December 1989.
} 
dollar has appreciated significantly in nominal terms (and very substantially in real terms) against the U.S. dollar since the first quarter of 1988 . The basic hypothesis, then, is that Australian interest rates are "high" because the market is anticipating a depreciation of the Australian dollar (i.e., the "peso" problem). ${ }^{6}$

One may well ask, of course, why that depreciation has not occurred already in view of a floating exchange rate (since December 1983) and relatively little intervention by the Reserve Bank. The answer to that would seem to be that (a) the current Labor government, locked into the famous "Accord" with the powerful Australian Congress of Trade Unions concerning nominal wages and with an eye to elections within the next ten months, is quite keen on avoiding the inflationary impact (and hence a decline in the real wage) that such a depreciation might create, and (b) the Reserve Bank, having converted most of its Treasury Bond holdings into a war chest of foreign exchange, can exert a massive influence on the foreign exchange market (for short periods at least) should a depreciation begin at a moment deemed inconvenient by the authorities.

In the section which follows, we develop a price-level determination model for a small open economy and, in Section III, it is fitted to the Australian data in search of evidence of "over valuation" of the Australian dollar in the market for goods. In Section IV, we examine the behavior of the both the nominal and "real" exchange rates in Australia seeking further

${ }^{6}$ The argument that the high interest rates are a result of the Australian dollar being temporarily over valued is not mutually exclusive with the argument that the cause is the current account deficit. Presumably much of the borrowing that leads to the deficit in the current account takes place first in the domestic capital market and is translated into a demand for foreign funds by the financial institutions; as such that borrowing puts pressure on domestic interest rates. This idea is examined in the final section of the paper. 
evidence of over valuation. The estimates obtained in Sections III and IV are consistent with over valuation, as of late 1988 and early 1989, of from five to nine per cent. In a final section, we search for evidence that the capital inflow itself may be the cause of the so-called over valuation; we also present the main conclusions in that section.

\section{THE MODEL}

Assume that there are two types of countries (or currency blocs) in the world: countries that are "large" in the sense that they can influence the world prices of traded goods, and "small" countries that have no appreciable power of that sort. The large countries are designated as "major-currency" countries, quite independent of the actual status of their currencies, and the small countries will be referred as "minor-currency" countries, even though their currencies may be quite important regionally. Since early 1973, all major-currency countries have operated under an exchange rate regime consisting of a money supply rule (a floating exchange rate). Australia will be treated as a small country, even though she may have considerable market power over the prices of some commodities.

Consider a particular good $i$ that is traded among $N$ countries (or currency blocs). ${ }^{7}$ We ignore transport costs, tariffs and other barriers to trade (as they are quite stable over time) and assume that the "law of one price" holds:

$$
P_{1, j}^{T}=E_{j k}+P_{1, k}^{T}
$$

\footnotetext{
${ }^{7}$ The model that is presented below first appeared in L. A. Sjaastad, "Exchange Rate Regimes and the Real Rate of Interest," in Michael Connolly and John McDermott (eds.), The Economics of the Caribbean Basin, Praeger Publishers, 1985. A somewhat similar approach has been developed by Rudiger Dornbusch; see his "Exchange Rate Economics," Economic Journal, March, 1987.
} 
where $\mathrm{P}_{i, j}^{\mathrm{T}}$ and $\mathrm{P}_{i, k}^{\mathrm{T}}$ are the (natural logarithms of the) prices of internationally traded good $i$ denominated in currencies of countries $\mathrm{J}$ and $k$, respectively, and $E_{j k}$ is the (natural logarithm of the) exchange rate between countries $\mathrm{J}$ and $\mathrm{K}$ (herein defined as the price of currency $\mathrm{k}$ in terms of currency $\mathrm{J}$ ). The excess demand, designated by $\mathrm{D}_{\mathrm{i}, \mathrm{k}}$, for internationally-traded good $\mathfrak{i}$ in country $\mathrm{x}$ is a decreasing function of the domestic real price of that good, and it also depends upon a vector $X_{i, k}$ of other relevant variables: ${ }^{8}$

$$
\begin{aligned}
D_{i, k} & =D_{i, k}\left(\left[P_{1, k}^{T}-P_{k}^{*}\right], X_{i, k}\right) \\
& =D_{i, k}\left(\left[P_{i, j}^{T}-E_{j k}-P_{k}^{*}\right], X_{1, k}\right)
\end{aligned}
$$

where $P_{k}^{*}$ is the (natural logarithm of the) price level in county $J$. The market-clearing condition is simply:

$$
\sum_{k=1}^{N} D_{i, k}=0 \text {. }
$$

Letting $d$ be the time-derivative operator and assuming continuous marking clearing, we differentiate equation (3) totally with respect to time to obtain an expression for the rate of change of the price of good $i$ in terms of currency $\mathrm{J}$ :

$$
\mathrm{dP}_{1, j}^{\mathrm{T}}=\sum_{\mathrm{k}=1}^{\mathrm{N}} \rho_{1, \mathrm{k}} \cdot\left(\mathrm{dE} \mathrm{jk}_{\mathrm{k}}+\pi_{\mathrm{k}}\right),
$$

where $\pi_{k} \equiv \mathrm{dP}_{k}^{*}$ is the rate of inflation in country $\mathrm{k}$ and $P_{\mathrm{i}, \mathrm{k}}$ is the relative contribution of country $k$ to the semi-elasticity of the world excess demand for good i with respect to its real price:

$$
\rho_{1, k}=\left[\partial D_{i, k} / \partial\left(P_{i, k}^{T}-P_{k}^{*}\right)\right] / D
$$

${ }^{8}$ As the attention is on exchange rates, this vector of other variables will be suppressed in what follows. 
$D$ being the sum of the individual country semi-elasticities:

$$
\mathrm{D}=\sum_{\mathrm{k}=1}^{\mathrm{N}}\left[\partial \mathrm{D}_{1, \mathrm{k}} / \partial\left(\mathrm{P}_{1, k}^{\mathrm{T}}-\mathrm{P}_{\mathrm{k}}^{*}\right)\right]
$$

As all excess demand functions have non-positive slopes and as the sum of the $\rho_{i, k}$ over $k$ is unity, it follows that each $\rho_{1, k}$ is a non-negative fraction.

The $\rho_{1, k}$ measure the ability of country $k$ to influence the price of good $i$ in the world market. If $\rho_{1,5}$ is zero, then country $s$ is a price taker in that market, as any changes in its exchange rate or its price level will not effect on the external price of good $i$. On the other hand, if $\rho_{\mathrm{i}, \mathrm{L}}$ is "large" (near unity), country $\mathrm{L}$ is a price maker; any change in its own price level (or exchange rate) will be reflected in a nearly equi-proportionate change in the price of good $i$ in all other currencies.

By integration, equation (4) becomes a "level" equation:

$$
P_{i, j}^{T}=\sum_{k=1}^{N} P_{i, k} \cdot\left(E_{j k}+P_{k}^{*}\right)+K,
$$

where $\mathrm{K}$ is the constant of integration. ${ }^{9}$

As $E_{j j} \equiv 0$, equation $\left(4^{\prime}\right)$ can be rewritten as:

$$
P_{i, j}^{T}=P_{j}^{*}+\sum_{k=1}^{N} P_{i, k} \cdot\left(E_{j k}+P_{k}^{*}-P_{j}^{*}\right) \text {, }
$$

the term in parentheses measuring departures from purchasing power parity between countries $J$ and $x$. Alternatively, it can be interpreted as the bilateral "real" exchange rate, defined as $E_{j k}^{R} \equiv E_{j k}+P_{k}^{*}-P_{j}^{*}$, between those countries:

${ }^{9}$ The term $\mathrm{K}$ reflects the variables that were suppressed earlier; in what follows, we shall also ignore $\mathrm{K}$. 


$$
P_{1, j}^{T}=P_{j}^{*}+\sum_{k=1}^{N} \rho_{1, k} \cdot E_{j k}^{R}+K
$$

To generalize expression (6) into a price index for all traded commodities, let $\omega_{1, j}$ be a set of non-negative weights that sum to unity:

$$
P_{j}^{T} \equiv \sum_{i=1}^{M} \omega_{i, j} \cdot P_{i, j}^{T}
$$

$\mathrm{P}_{j}^{\mathrm{T}}$ is a price index, in currency $\mathrm{J}$, of the $\mathrm{M}$ internationally-traded commodities. Combining equations (6) and (7), we obtain:

$$
\begin{aligned}
P_{j}^{T} & =P_{j}^{*}+\sum_{i=1}^{M} \sum_{k=1}^{N}\left[\omega_{1, j} \cdot \rho_{i, k} \cdot\left(E_{j k}+P_{k}^{*}-P_{j}^{*}\right)\right] \\
& =P_{j}^{*}+\sum_{k=1}^{N}\left[\theta_{k, j} \cdot\left(E_{j k}+P_{k}^{*}-P_{j}^{*}\right)\right] \\
& =P_{j}^{*}+\sum_{k=1}^{N} \theta_{k, j} \cdot E_{j k}^{R},
\end{aligned}
$$

where $\theta_{k, j} \equiv \sum_{i=1}^{M} \omega_{1, j} \cdot \rho_{i, k}$ are non-negative fractions that sum to unity:

$$
\begin{aligned}
\sum_{k=1}^{N} \theta_{k, j} & =\sum_{i=1}^{M}\left[\omega_{i, j} \cdot \sum_{k=1}^{N} \rho_{i, k}\right] \\
& =\sum_{i=1}^{M} \omega_{1, j} \\
& =1.0 .
\end{aligned}
$$

The $\theta_{k, j}$ are similar to the $\rho_{1, k}$ except that they measure the power enjoyed by country $x$ in the world market over a set of internationally traded goods. Country $s$ is "small" if $\theta_{s, j}$ is "small" for all $\mathrm{J}$.

Price Level Determinants in a Small Country

Defining a country's price level as a geometrically-weighted average of domestic prices of her traded and nontraded goods:

$$
\mathrm{P}_{\mathrm{S}}^{*}=\alpha_{\mathrm{S}} \cdot \mathrm{P}_{\mathrm{S}}^{\mathrm{T}}+\left(1-\alpha_{\mathrm{S}}\right) \cdot \mathrm{P}_{\mathrm{S}}^{\mathrm{H}}
$$

where $P_{S}^{T}$ is the price index for traded goods and $P_{S}^{H}$ is a price index 
for nontraded goods in that country, and assuming that the law of one price holds between country $s$ and country $J\left(P_{1,5}^{T}=P_{1, J}^{T}+E_{S J}\right)$, we obtain an index for the internal prices of traded goods in country $s$ :

$$
\begin{aligned}
P_{S}^{T} & =E_{S J}+\sum_{1=1}^{M} \omega_{1,5} \cdot P_{1, J}^{T} \cdot \\
& =E_{S J}+P_{J}^{*}+\sum_{k=1}^{N} \theta_{k, S} \cdot E_{J k}^{R},
\end{aligned}
$$

where $\theta_{k, s}$ is defined on weights relevant for country $s$.

The price level of country $s$ can be expressed as a relative price together with the price of traded goods:

$$
P_{S}^{*}=\left(1-\alpha_{S}\right) \cdot\left(P_{S}^{H}-P_{S}^{T}\right)+P_{S}^{T},
$$

and, using equation (9), the relative price can be expressed as a weighted average of the bilateral "real" exchange rate between country $s$ and the rest of the world:

$$
\begin{aligned}
\left(1-\alpha_{s}\right) \cdot\left(P_{S}^{T}-P_{S}^{H}\right) & =P_{S}^{T}-P_{S}^{*} \\
& =\sum_{k=1}^{N}\left(\theta_{k, s} \cdot E_{J k}^{R}\right)+\left(E_{S J}+P_{J}^{*}-P_{S}^{*}\right) \\
& =\sum_{k=1}^{N}\left[\theta_{k, s} \cdot\left(E_{J k}^{R}+E_{S J}^{R}\right)\right] \\
& =\sum_{k=1}^{N} \theta_{k, s} \cdot E_{S k}^{R} \equiv E_{S}^{R} .
\end{aligned}
$$

That weighted average, defined as $\mathrm{E}_{\mathrm{S}}^{\mathrm{R}}$, is the multilateral (or true) "real" exchange rate for country s.

Substituting equations (10) and (11) into (9) gives us a convenient expression for describing the forces that influence the price level of country s:

$$
\mathrm{P}_{\mathrm{S}}^{*}=-\mathrm{E}_{\mathrm{S}}^{\mathrm{R}} \cdot+\left(\mathrm{E}_{\mathrm{SJ}}+\mathrm{P}_{\mathrm{J}}^{*}\right)+\sum_{\mathrm{k}=1}^{\mathrm{N}} \theta_{\mathrm{k}, \mathrm{S}} \cdot \mathrm{E}_{J k}^{\mathrm{R}} .
$$

This expression has three quite distinct components: 
(a) the multilateral "real" exchange rate, $E_{s}^{\mathrm{R}}$, which reflects the (endogenous) internal relative price structure of that country;

(b) a purchasing power parity component, $\left(\mathrm{E}_{\mathrm{SJ}}+\mathrm{P}_{\mathrm{J}}^{*}\right)$, reflecting the fact that the exchange rate of country $s$ has been defined on on the currency of country $\mathrm{J}$; and

(c) an exogenous component reflecting the existing structure of "real" exchange rates among the rest of the countries in the world.

The sum of the last two terms on the right hand side of equation (12) should be thought of as the "external" influence on the price level of country s. ${ }^{10}$

\section{THE AUSTRALIAN PRICE LEVEL}

The Figure on the following page presents the Australian price level (in domestic currency) and the external price of Australian traded goods (in U.S. dollars) from 1972 through 1988. The "internal price" is ACPI, and the "external price" is a simple average of the U.S. dollar unit values of Australian imports and exports (TUV). Apart from upward trends, there

${ }^{10} \mathrm{~A}$ further comment on the use of "real." exchange rates is indicated by the above. By rearrangement of equation (12), we obtain:

$$
E_{s J}^{R}=E_{s}^{R} \cdot-\sum_{k=1}^{N} \theta_{k, s} \cdot E_{J k}^{R},
$$

that is, the bilateral "real" exchange rate is the difference between the multilateral "real" exchange rate and a weighted average of "real" exchange rates between country $J$ and all third countries. Consequently, fluctuations in the "real" exchange rates between the reference country and all third countries will be reflected in the bilateral "real" exchange rate. If, say, the U.S. is the reference country, a 10 per cent real. depreciation of the U.S. dollar against all major currencies may lead to a substantial real appreciation of the bilateral "real" exchange rate of country $s$ with respect to the U.S., even though no change has occurred in the multiliatoral (or lirug) "ronl" axchange ratio of counliry a. Owing lin the volatility of the "real" exchange rates between the major currency countries since 1973, this phenomenon can lead-indeed, has lead-to a great deal of confusion. 


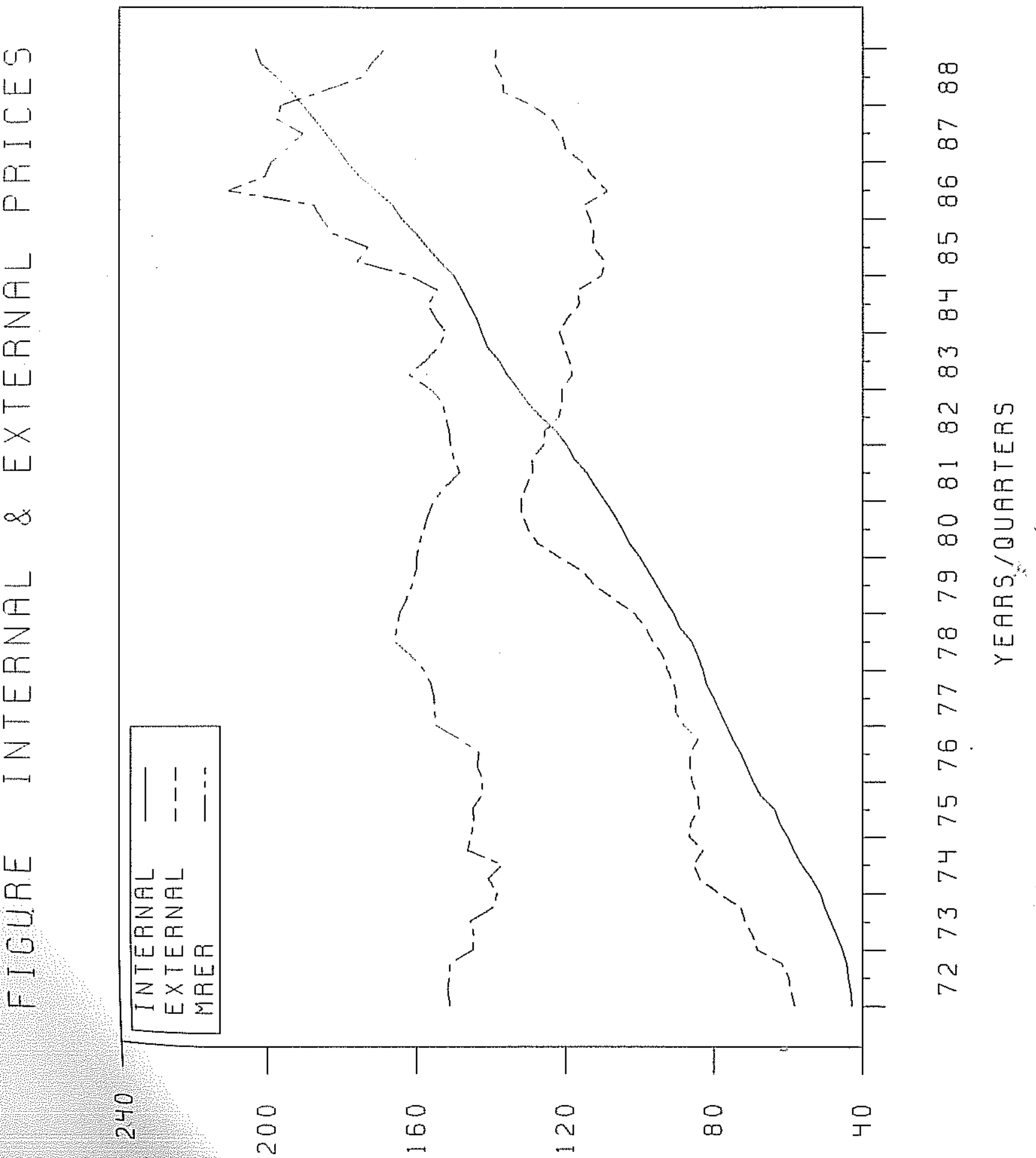


seems to be no relationship between the two series. We shall see, however, that external prices have a very strong potential impact on the Australian price level, but movements in the former are largely neutralized by the Australian exchange rate.

\section{Empirical Implementation}

Equation (12) is not convenient for estimation; rather we will begin anew by combining equations (8) and (9). Moreover, we will limit our attention to four potentially large countries: the United States, Germany (as a proxy for Europe), Japan, and Australia. Equation (8) for Australia becomes:

$$
\mathrm{P}_{\mathrm{A}}^{\mathrm{T}}=\mathrm{P}_{\mathrm{A}}^{*}+\theta_{\mathrm{US,A}} \cdot \mathrm{E}_{\mathrm{A}, \mathrm{US}}^{\mathrm{R}}+\theta_{\mathrm{G}, \mathrm{A}} \cdot \mathrm{E}_{\mathrm{A}, \mathrm{C}}^{\mathrm{R}}+\theta_{\mathrm{N}, \mathrm{A}} \cdot \mathrm{E}_{\mathrm{A}, \mathrm{N}}^{\mathrm{R}},
$$

where the subscripts $A$, us, $G$, and $N$ refer to Australia, the United States, Germany, and Japan, respectively. Combining equations ( $\left.8^{\prime}\right)$ with (9), we obtain an expression that is convenient for estimation:

$$
\begin{aligned}
P_{A}^{*}= & \beta_{O}+\beta_{1} \cdot P_{A}^{H}+\beta_{A} \cdot E_{A, U S}+\beta_{U S} \cdot P_{U S}^{*}+\beta_{G} \cdot\left(E_{U S, C}+P_{G}^{*}\right) \\
& +\beta_{N} \cdot\left(E_{U S, N}+P_{N}^{*}\right),
\end{aligned}
$$

where the $\beta_{j}$ are combinations of the coefficients in equations ( $8^{\prime}$ ) and (9). ${ }^{11}$ Note that the final three elements of equation (13) are all in terms

${ }^{11}$ The complete expression is:

$$
\begin{aligned}
P_{A}^{*}[1- & \left.\alpha_{A}\left(1-\theta_{U S, A}-\theta_{G, A}-\theta_{N, A}\right)\right]=\left(1-\alpha_{A}\right) P_{A}^{H} \\
& +\left[\alpha_{A}\left(\theta_{U S, A}+\theta_{C_{A}, A}+\theta_{N, A}\right)\right] E_{\Lambda, U S}+\left(\alpha_{A} \cdot \theta_{U S, A}\right) P_{U S}^{*} \\
& +\left(\alpha_{A} \cdot \theta_{G, A}\right)\left(E_{U S, G}+P_{G}^{*}\right)+\left(\alpha_{A} \cdot \theta_{N, A}\right)\left(E_{U S, N}+P_{N}^{*}\right) .
\end{aligned}
$$

If the four countries in question are the only "large" countries in the world, then:

$$
\theta_{\mathrm{A}, \mathrm{A}}+\theta_{\mathrm{US}, \mathrm{A}}+\theta_{\mathrm{C}, \mathrm{A}}+\theta_{\mathrm{N}, \mathrm{A}}=1
$$

and the above equation can be written as:

$$
P_{A}^{*}=\left[\left(1-\alpha_{A}\right) / \gamma_{A}\right] P_{A}^{H}+\left[\alpha_{A}\left(1-\theta_{A, A}\right) / \gamma_{A}\right] E_{A, U S}+\left(\alpha_{A} \cdot \theta_{U S, A} / \gamma_{A}\right) P_{U S}^{*}
$$


of the same currency-the U.S. dollar. As all variables are in index form, $\beta_{0}$ is an arbitrary constant. The following implicit constraints on the $\beta$ coefficients are directly implied by the homogeneity postulate: ${ }^{12}$

1) $\beta_{1}+\beta_{U S}+\beta_{G}+\beta_{N}=1.0$,

2) $\beta_{1}+\beta_{A}=1.0$.

Equation (13) was estimated using quarterly data for the period 1972:1 to 1988:4. The price data are consumer price indices obtained from the International Monetary Fund International Financial Statistics (IFS), as were the exchange rates; other data, such as the Australian wage rate, are from the Australian Bureau of Statistics. All coefficients had the expected sign and are highly significant. Although serial correlation abounds in these data, a highly significant $Q$ statistic indicated that it was successfully removed from the residuals. The tests of the constraints described earlier produced mixed results. The test of the first constraint is indicates that it was not violated, as the sum of the coefficients of exchange rate price level variables was 1.04 and not significantly different from unity. However, the test of the second constraint (which involves the coefficients of the prices of foreign exchange and nontraded goods) clearly failed as the sum of the relevant coefficients is 0.66 -and significantly less than unity.

Moreover, the results suggest that the power of the U.S. in international markets for Australian traded goods is implausibly large

$$
+\left(\alpha_{A} \cdot \theta_{G, A} / \gamma_{A}\right)\left(E_{U S, G}+P_{C}^{*}\right)+\left(\alpha_{A} \cdot \theta_{N, A} / \gamma_{A}\right)\left(E_{U S, N}+P_{N}^{*}\right)
$$

in which each coefficient has a common denominator: $\gamma_{A}=1-\alpha_{A} \cdot \theta_{A, A}$. That common denominator becomes unity if Australia has no power in the world markets for her tradeables.

${ }^{12}$ The reader can verify from the immediately preceding footnote that these constraints do not depend upon Australia being a "small" country. 
compared with that of Japan and Europe (the estimates of the elasticities the three countries, which are proportional the to $\theta_{k, A}$, were 0.444 , 0.077 and 0.068 , respectively). There is a potential bias in these estimates, however, one that may cause the coefficients for European and Japanese price indices to be understated relative to the U.S. The reason for this is that, whereas the U.S. consumer price index is a very "smooth" series, the German and Japanese indices, having been multiplied by highly volatile exchange rates, are quite "choppy". The result is that there may be considerable measurement error in the latter two indices, leading to a downward bias on their coefficient estimates in the regression.

To address this problem, we modified the price data so that all series are equally "choppy" by defining all price levels and exchange rates in terms of a "basket" of currencies rather than the U.S. dollar. Details concerning the specification of the basket, which includes just three currencies (the U.S. Dollar, the German DM, and the Japanese Yen), are presented in the Appendix.

Equation (13) must be modified for the "basket" approach; to do so, let $E_{j}$ be the (natural logarithm of the) price of the currency basket in units of currency $J$ and $P_{j b}^{*}$ the (natural logarithm of the) price level in country $J$ measured in units of that basket, which leads to the following relationships:

$$
\begin{aligned}
& E_{1 j}=E_{i}-E_{j}, \\
& P_{j}^{*}=P_{j b}^{*}+E_{j} .
\end{aligned}
$$

Substituting these relationships into equation (14) produces the following version of that equation:

$$
P_{A}^{*}=\beta_{0}+\beta_{1} \cdot P_{A}^{H}+\beta_{A} \cdot E_{A}+\beta_{U S} \cdot P_{U S, b}^{*}+\beta_{G} \cdot P_{C, b}^{*}+\beta_{N} \cdot P_{N, b}^{*} \cdot
$$

The estimation of equation (14) was by iteration; beginning with an arbitrary composition of the basket, we estimated the $\beta_{j}$, and then 
calculated the new composition of the basket in accordance with equations (A7.) of the Appendix. The iterations converged quickly, and the (average) shares of the final basket were $0.349,0.249$, and 0.402 for the U.S. dollar, the German DM, and the Japanese yen, respectively. ${ }^{13}$

The results of the final iteration of equation (14) are presented in Table 2 below. ${ }^{14}$ All variables are in logs. The dependent variable, $A C$, is the Australian consumer price index. The price of nontraded goods is represented by the Australian wage rate, AW, with one and two quarter lags. The Australian dollar price of the U.S. dollar is the variable AX, with lags of zero and one. The variable AXB is the Australian dollar price of the basket and corresponds to $\mathrm{E}_{\mathrm{A}}$ in equation (14). The variables USCB, GCB and NCB (which correspond to the $\mathrm{P}_{\text {, }}^{*}$ ) are the U.S., German, and Japanese price levels, respectively, measured in terms of the basket. Two additional variables, the internal and external terms of trade were added; the internal terms of trade, denoted by $\mathrm{TT}$, is the (natural logarithm of the) ratio of the Australian wage rate (AW) to a simple average of the IFS Indlces for the internal prices of limports and exports in Australian dollars. The external terms of trade, denoted by ATT, is the (natural logarithm of the) ratio of the index for the internal price of

${ }^{13}$ The initial basket was chosen such that the shares were all one-third. As the average DM and Yen prices of the U.S. dollar during the period were DM 2. 36 and Yen 236, respectively, the dollar value of the basket is given by:

$$
e_{u S}=0.349+0.249 \cdot\left(2.36 \cdot e_{u s, G}\right)+0.402 \cdot\left(236 \cdot e_{u S, N}\right)
$$

where $e_{k, j}$ is the arithmetic value of the price of currency $J$ in terms of currency $\mathrm{K}$.

${ }^{14} \mathrm{All}$ regressions were run using version 3.03 of RATS (VAR Econometrics). As the constant term has no interpretation, it is not reported in this or any of the following Tables. 
TABLE 2

"BASKET" REGRESSION EQUATION FOR THE AUSTRALIAN PRICE LEVEL DEPENDENT VARIABLE: AC METHOD: MA

FROM $72: 3$ UNTIL $88: 4$

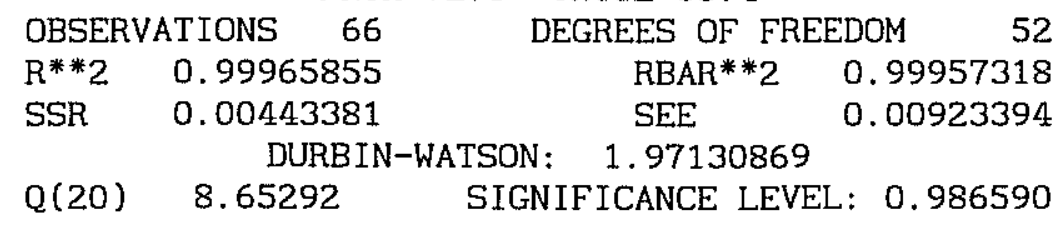

\begin{tabular}{|c|c|c|c|c|c|}
\hline $\begin{array}{l}\text { VARIABLE } \\
* * * * * * * *\end{array}$ & LAG & $\begin{array}{l}\text { COEFFICIENT } \\
* * * * * * * * * * *\end{array}$ & $\begin{array}{l}\text { T-STATISTIC } \\
* * * * * * * * * * * *\end{array}$ & $\underset{\text { SIGNIF. }}{\text { SI********* }}$ & $\underset{* * * * * *}{\mathrm{LEVEL}}$ \\
\hline AW & 1 & 0.3174869 & 4.733096 & 0.1739039 & $E-0$ \\
\hline $\mathrm{AW}$ & 2 & 0.1847945 & 2.523407 & 0.0147176 & \\
\hline AXB & 0 & 0.1559110 & 4.983345 & 0.7300321 & $E-c$ \\
\hline $\mathrm{AXB}$ & 1 & 0.1079650 & 4.496027 & 0.3903864 & $E-C$ \\
\hline USCB & 0 & 0.1755034 & 3.263965 & 0.0019455 & \\
\hline GCB & 0 & 0.1250577 & 2.623364 & 0.0113992 & \\
\hline NCB & 0 & 0.2022602 & 3.540193 & 0.8526425 & $5 E-C$ \\
\hline $\mathrm{TT}$ & 0 & 0.1456137 & 3.527264 & 0.8868776 & $E-1$ \\
\hline ATT & 0 & 0.1362490 & 2.330264 & 0.2370745 & \\
\hline MVG AVGE & 1 & 1. 3198260 & 8.698392 & 0.1019905 & $E-$ \\
\hline MVG AVGE & 2 & 1.2354690 & 5.332997 & 0.2126400 & $E-$ \\
\hline MVG AVGE & 3 & 0.7466937 & 3.367769 & 0.0014327 & \\
\hline MVG AVGE: & 1 & 0.2113270 & 1.168656 & 0.1179199 & \\
\hline
\end{tabular}

TESTS ON REGRESSION COEFFICIENTS:

ON THE SUM OF COEFFICIENTS:

Series: $\mathrm{AW}_{-1}, \mathrm{AW}_{-2}, \mathrm{AXB}, \mathrm{AXB}_{-1}$ VALUE $\quad 0.766157$ STD ERR 0.061444 T-STAT 12.469160
ON THE SUM OF COEFFICIENTS:

Series: $\mathrm{AW}_{-1}, \mathrm{AW}_{-2}, \mathrm{USCB}, \mathrm{GCB}, \mathrm{NCB}$

$\begin{array}{lr}\text { VALUE } & 1.005103 \\ \text { STD ERR } & 0.052874 \\ \text { T-STAT } & 19.009280\end{array}$

exports to the corresponding index for imports.

The overall quality of the $f i t$, as indicated by the t-ratios, is substantially better than with the original version of the price equation. The coefficients are all highly significant, and the implausible dominance of the U.S. price level has disappeared. Indeed, the effect of Japan on the Australian price level is now larger than that of the U.S.

A test for "over-valuation" of the Australian dollar during 1988 was conducted on the "basket" specification of the price level equation by use 
of dummy variables that took a value of unity for the quarter in question and zero for all other quarters; the results are reported in Table $3 .^{15}$ The coefficient estimates are quite similar to those in Table 2 , and the degree of "over-valuation" during the last quarter of 1988 (the coefficient of D884) is .078 and the coefficient is highly significant. ${ }^{16}$ That is, the Australian price level was about 7.8 per cent higher during the last quarter of 1988 than one would have predicted on the basis of the post-1972 relationship of that price level with the exchange rate and external prices. The price level, of course, can never be "too high" in any absolute sense, it can only be "too high" relative to the exchange rate and external prices; that the price level was "too high", can only mean that the exchange rate was "too low". The implication, then, is that during the final quarter of 1988, the Australian dollar was over valued (in the goods market) by about 7.8 per cent.

\section{THE AUSTRALIAN EXCHANGE RATE}

The above results seem to fly in the face of the conventional wisdom in Australia that the Australian dollar is a "commodity currency". A remarkable feature of the Australian inflation rate is its high degree of stability, a stability that has not been achieved in many other countries via the use of either exchange rate or monetary policy. As the Figure

\footnotetext{
${ }^{15}$ The estimates presented in Tables 3 and 4 are based on the same currency basket.

${ }^{16}$ The variable D884 has a value of 1.0 for the fourth quarter of 1984 and zero for all other quarters. The coefficient of this variable is the estimated residual for that quarter, and the standard error of that coefficient is the estimate of the standard error of the estimate of the residual for that quarter. The same holds for D883, D882, and D881. These three additional dumy variables were introduced because of the moving average representation of the residuals that was employed to deal with the serial correlation problem.
} 
TABLE 3

TEST OF OVER VALUATION OF THE AUSTRALIAN DOLLAR: 1988

DEPENDENT VARIABLE: AC METHOD: MA

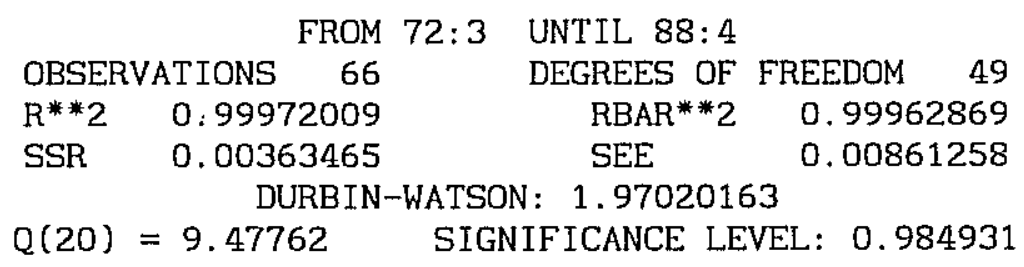

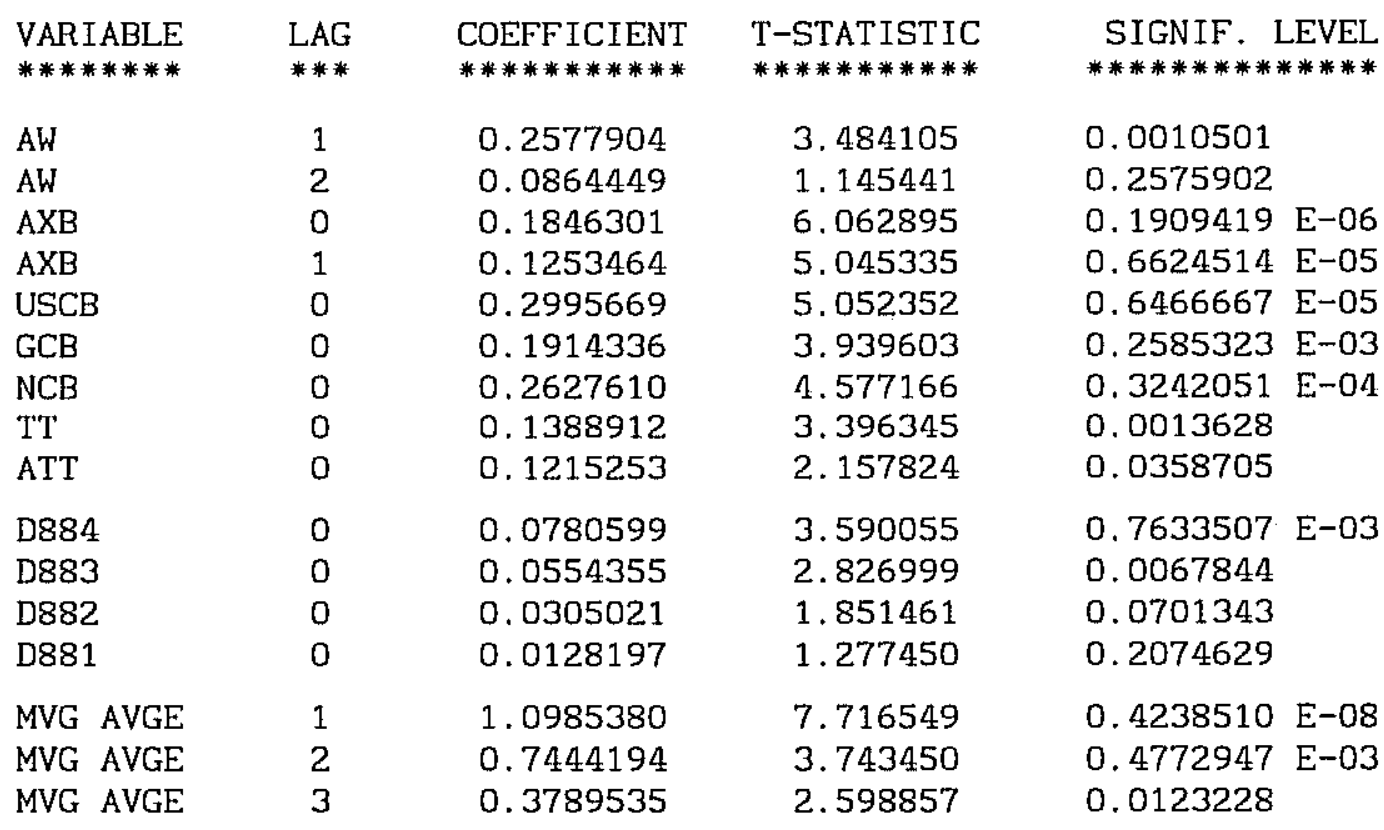

TESTS ON REGRESSION COEFFICIENTS:

ON THE SUM OF COEFFICIENTS:

Series: $\mathrm{AW}_{-1}, \mathrm{AW}_{-2}, \mathrm{AXB}, \mathrm{AXB}_{-1}$

$\begin{array}{lllr}\text { VALUE } & 0.654212 & \text { VALUE } & 1.097997 \\ \text { STD ERR } & 0.065723 & \text { STD ERR } & 0.053443 \\ \text { T-STAT } & 9.954100 & \text { T-STAT } & 20.545516\end{array}$

referred to earlier indicates, the Australian price level was been

insulated from the large swings in external prices that occurred during the 1973-88; the world dollar inflation of 1975-80 was not transmitted to the Australian economy, nor was the subsequent world dollar deflation of 1980-85. One suspects that one reason for this high degree of stability lies in the institutional structure of the Australian economy. In addition to the Reserve Bank and the Treasury, there is the (former) Arbitration 
Board, which has an important role in wage determination, particularly for the unionized (including the public) sector. Wages levels for a large part of the Australian economy are "predetermined" by contracts that have the blessing of the Arbitration Board; consequently, the role of exchange rate and/or monetary policy is the subsidiary one of validating the wage agreements that have already been made. The hypothesis, then, is that the fundamental numeraire of the Australian economy is the wage rate, and that monetary and exchange rate policy are used to influence the price level to maintain a real wage that is consistent. with labor market: equilibrium.

Behavior of The Nominal Exchange Rate

As a tentative test of this hypothesis, we estimated equations in which the (natural logarithm of the) exchange rate was the dependent variable, and the independent variables consisted of (i) a one-quarter lag on the exchange rate, (ii) the (natural logarithm of the) wage rate with is both leads and lags, as a proxy for the prices of nontraded goods, and (iii) the (natural logarithm of the) contemporary and lagged values of a simple average of the indices of the external prices (in U.S. dollars) of Australian imports and exports, TUV. The estimated equations are of the following general form: ${ }^{17}$

\footnotetext{
${ }^{17}$ Equation (15) also provides a test of the purchasing power parity (PPP) doctrine. In its strongest form, that doctrine indicates that the (sum of the) coefficient(s) of the wage variable(s) should be unity, and that the (sum of the) coefficient(s) of the external price variable(s) should be minus unity. A weaker form of that doctrine requires only that the coefficients of the wage and external price variables sufil to zero: a one per cent increase in nominal wages together with a one per cent increase in external prices will produce no change in the real wage only if the exchange rate remains constant. The short run impact of changes in the wage rate and external prices are given by the coefficients b and $c$; in the long run, however, those impacts are $b_{1}=b /(1-a)$ and $c_{1}=c /(1-a)$, respectively. Obviously, the hypothesis that $b_{1}=1$ implies that $(a+b)=1$; similarly, if $c_{1}=-1$, then it follows that
} 


$$
A X=\text { constant }+a \cdot A X_{-1}+b \cdot A W+c \cdot T U V .
$$

Both current and lagged values of the external prices of traded goods (TUV) were included to provide further dynamics in equation (15), and the results are reported in Table $4 .^{18}$ In particular, we want to see if an unexpected but temporary change in TUV causes the exchange rate to move in the opposite direction to (partially) offset that unexpected change, but then return to the path that it would have followed had the temporary shock in the external price of traded goods not occurred.

The results indicate that over 80 per cent of short-run fluctuations in external prices of traded goods are neutralized in the same quarter (the coefficient of contemporary TUV being -0.854). That is, if TUV rises by ten per cent, the Australian dollar is revalued by 8.5 per cent. However, only 10 per cent of an expected increase in the future wage rate is immediately reflected in the exchange rate, the remainder being distributed over time. ${ }^{19}$ The dynamics implied by the coefficients are quite interesting and consistent with the type of causality between wages,

$(a-c)=1$. The PPP propositions are tested in accordance with these implied restrictions on the two linear combinations of $a, b$ and $c$. ${ }^{18}$ This required extending the wage variable to the second quarter of 1989. The structure of the serial correlation in the residuals of the equation presented in Table 4 is quite complex and was removed by a filter. The filter was created by regressing the residuals of an OLS estimate of equation 15 on their lagged values (eight quarters); this filter was then applied to all relevant variables, and the filtered variables were then used in the regressions reported in Tables 4 and 5 below.

${ }^{19}$ The results of the PPP tests are quite decisive; neither the sum of the coefficients of the leading wage rate and the lagged exchange rate $[(a+b)$ from equation (15)] nor the difference between the coefficients of the leading wage rate and current and lagged external prices of traded goods [ $(a-c)$, also from equation (15)] are significantly different from unity; the $T$ ratios on those tests are 1.38 and 0.57 , respectively. The weak test of PPP, which requires the wage rate and external price coefficients $(b+c)$ to sum to zero, also is not rejected, as that sum is merely 0.0025 with a standard eггог of 0.0282 . 


\section{TABLE 4}

TEST OF CAUSALITY BETWEEN EXTERNAL PRICES AND THE EXCHANGE RATE DEPENDENT VARIABLE: AX METHOD: FILTERED OLS

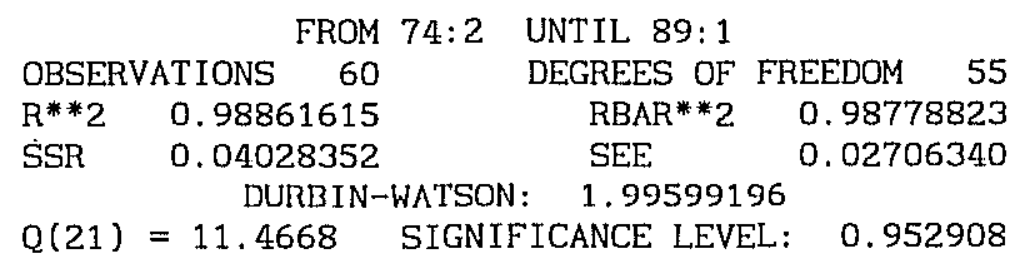

\begin{tabular}{|c|c|c|c|c|}
\hline $\begin{array}{l}\text { VARIABLE } \\
* * * * * * * * *\end{array}$ & $\begin{array}{l}\text { LAG } \\
* * *\end{array}$ & $\begin{array}{l}\text { COEFFICIENT } \\
* * * * * * * * * * *\end{array}$ & $\begin{array}{l}\text { T-STATISTIC } \\
* * * * * * * * * * *\end{array}$ & 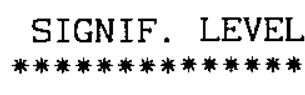 \\
\hline$A X$ & 1 & 0.87379320 & 8.550025 & 0.3730160 \\
\hline AW & -1 & 0.09900687 & 1.047793 & 0.2993169 \\
\hline TUV & 0 & -0.85399920 & -8.083490 & 0.3782758 \\
\hline TUV & 1 & 0.75248080 & 4.998709 & 0.6225634 \\
\hline
\end{tabular}

TESTS OF STRONG PPP (EQ. 15):

SUM OF COEFF. $(\mathrm{a}+\mathrm{b}=1)$ :

Series: $A X_{-1}, A W_{+1}$

VALUE

STD ERR

T-STAT
0.972800
0.019699
1.380781

DIFF. BETWEEN COEFF. $(a-c=1)$ :

Series: $A_{-1}$, TUV, TUV -1

VALUE $\quad 0.975312$

STD ERR 0.043531

T-STAT $\quad 0.567136$

TEST OF WEAK PPP (EQ. 15):

SUM OF COEFF. $(b+c=0)$ :

SERIES: $\mathrm{AW}_{+1} ; \mathrm{TUV}, \mathrm{TUV}_{-1}$

$\begin{array}{llll}\text { VALUE } & -0.002512 \quad \text { STD ERR } & 0.028181\end{array}$

T-STAT $\quad-0.089124$

external prices, and the exchange rate that was hypothesized above. A temporary (one period) rise (fall) in the price of traded goods (TUV) is largely offset by a contemporaneous appreciation (depreciation) of the exchange rate. One quarter later, the temporary rise in TUV appears in its lagged value, and the appreciation of the exchange rate appears in the lagged value of the exchange rate; the coefficients are such that the exchange rate is restored almost exactly to the value it would have had if 
no (temporary) change in the price of traded goods had occurred. ${ }^{20}$ The quantitative effect of a single period increase in TUV on the exchange rate during the following period is given by:

$$
\begin{aligned}
& \mathrm{dAX}_{1} / \mathrm{dTUV}_{0}=\left(\partial \mathrm{AX}_{1} / \partial \mathrm{AX}_{0}\right)\left(\partial \mathrm{AX}_{0} / \partial \mathrm{TUV} \mathrm{V}_{0}\right)+\left(\partial \mathrm{AX} \mathrm{X}_{1} / \partial \mathrm{TUV} \mathrm{V}_{0}\right) \\
& =(0.8738)(-0.8540)+0.7525=0.0063 \text {, }
\end{aligned}
$$

whose standard error is approximately $0.0323 .^{21}$

The response of the exchange rate to wage bargains and external prices changed markedly with the introduction of the floating rate policy in late 1983. A dumny variable (DUM) whose value is zero until the last quarter of 1983 but thereafter is equal to unity was introduced to modify the coefficients of all variables (including the constant term) of equation (15). As an $F$ test indicated that the contemporary wage variable, and the corresponding dummy for that variable, as well as lagged external prices were not (jointly) significant, those variables were not included in the regression. ${ }^{22}$ The results are reported in Table 5.

"Note that the "exclude test" in the bottom half of Table 4 indicates that leading wages and lagged prices of traded goods are jointly significant; those variables cannot be eliminated from the regression.

${ }^{21}$ Writing the estimated equation as:

$$
\mathrm{AX}_{\mathrm{t}}=\text { constant }+\alpha \cdot \mathrm{AX}_{\mathrm{t}-1}+\beta \cdot \mathrm{AW}_{\mathrm{t}+1}+\gamma \cdot \mathrm{TUV}_{\mathrm{t}}+\delta \cdot \mathrm{TUV}_{\mathrm{t}-1}+\mathrm{u}_{\mathrm{t}},
$$

it follows that $\left(\partial \mathrm{AX}_{\mathrm{t}} / \partial \mathrm{TUV}_{\mathrm{t}-1}\right)=\alpha \cdot \gamma+\delta=\mathrm{F}(\alpha, \gamma, \delta)$, whose variance is approximately $F_{\alpha}^{2} \cdot \sigma_{\alpha}^{2}+F_{\gamma}^{2} \cdot \sigma_{\gamma}^{2}+F_{\delta}^{2} \cdot \sigma_{\delta}^{2}+2\left(F_{\alpha} \cdot F_{\gamma} \cdot \sigma_{\alpha \gamma}^{2}+F_{\alpha} \cdot F_{\delta} \cdot \sigma_{\alpha \delta}^{2}+F_{\gamma} \cdot F_{\delta} \cdot \sigma_{\gamma \delta}^{2}\right)$ $=\gamma^{2} \cdot \sigma_{\alpha}^{2}+\alpha^{2} \cdot \sigma_{\gamma}^{2}+\sigma_{\delta}^{2}+2\left(\alpha \cdot \gamma \cdot \sigma_{\alpha \gamma}^{2}+\gamma \cdot \sigma_{\alpha \delta}^{2}+\alpha \cdot \sigma_{\gamma \delta}^{2}\right)$, where $\sigma_{1}^{2}$ is the variance of the estimate of coefficient $i$ and $\sigma_{1 j}^{2}$ is the covariance between the estimates of coefficients $i$ and $j$. The estimate of the variance is 0.00104 .

${ }^{22}$ The dummy variables corresponding to the (lagged) dependant variable, the (leading) wage rate, and (contemporary) external prices are labelled DAX, DAW, and DTUV, respectively. 
TABLE 5

TEST OF STRUCTURAL SHIFT IN RELATIONSHIP BETWEEN EXTERNAL PRICES AND THE EXCHANGE RATE DEPENDENT VARIABLE: AX METHOD: FILTERED OLS

FROM 74:2 UNTIL 89:1

\begin{tabular}{lrrrr}
\multicolumn{2}{l}{ OBSERVATIONS 60} & DEGREES OF & FREEDOM 48 \\
$\mathrm{R}^{* * 2}$ & 0.99857634 & RBAR**2 & 0.99825008 \\
SSR & 0.02007664 & SEE & 0.02045149
\end{tabular}

DURBIN-WATSON: 2.15038184

$\mathrm{Q}(20) \quad 12.1853 \quad$ SIGNIFICANCE LEVEL 0.934479

\begin{tabular}{|c|c|c|c|c|}
\hline 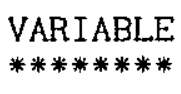 & $\begin{array}{l}\text { LAG } \\
* * *\end{array}$ & $\begin{array}{l}\text { COEFFICIENT } \\
* * * * * * * * * * *\end{array}$ & $\begin{array}{l}\text { T-STATISTIC } \\
* * * * * * * * * * *\end{array}$ & 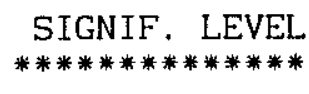 \\
\hline$A X$ & 1 & 0.7196435 & 6.200386 & $0.1238240 \mathrm{E}-06$ \\
\hline DAX & 1 & -0.4197015 & -3.689364 & $0.5730824 \quad E-03$ \\
\hline$A W$ & -1 & 0.2051926 & 2.261763 & 0.02827897 \\
\hline DAW & -1 & 0.6112093 & 4.267935 & $0.9238028 \quad E-04$ \\
\hline TUV & 0 & -0.3884335 & -3.518805 & $0.9597939 E-03$ \\
\hline DTUV & 0 & -0.6955977 & -5.882012 & $0.3794809 E-06$ \\
\hline TUV & 1 & 0.2424989 & 1.505592 & 0.1387247 \\
\hline DUM & 0 & 0.3262093 & 0.328218 & 0.7441743 \\
\hline D891 & 0 & -0.0935222 & -2.306706 & 0.02543122 \\
\hline D884 & 0 & -0.0654508 & -2.040362 & 0.04683612 \\
\hline D883 & 0 & -0.0378956 & -1.324111 & 0.19173710 \\
\hline
\end{tabular}

TEST OF HYPOTHESIS THAT CONTEMPORARY AW AND DAW, AND LAGGED DTUV ARE IRRELEVANT:

NULL HYPOTHESIS: THE FOLLOWING COEFFICIENTS ARE ZERO: SERIES: AW, DAW, DTUV $F(3,48)=0.589683$, SIGNIFICANCE LEVEL: 0.6267510 TESTS ON REGRESSION COEFFICIENTS:

SUM OF COEFF.

$\begin{array}{lrl}\text { SERIES: } & \mathrm{AW}_{+1}, \mathrm{DAW}_{+1} \\ \text { VALUE } & & 0.816402 \\ \text { STD ERR } & & 0.169497 \\ \text { T-STAT } & & 4.816618\end{array}$

SUM OF COEFF SERTES: TUV, DTUV

$\begin{array}{lr}\text { VALUE } & -1.084031 \\ \text { STD ERR } & 0.110202 \\ \text { T-STAT } & -9.836796\end{array}$

SUM OF COEFF.

SERIES: $\mathrm{AX}_{-1}, \mathrm{DAX}_{-1}$

$\begin{array}{cccc}\text { VALUE } & 0.2999420 & \text { STD ERR } & 0.1351192 \\ & \text { T-STAT } & 2.219832 & \end{array}$

Cont inued. . . . . 


\section{TABLE $5-$ CONTINUED}

TESTS OF STRONG PPP (EQ. 15) UNDER FIXED RATE:

SUM OF COEFF. $(a+b=1)$ :

DIFF. BETWEEN COEFF. $(a-c=1)$ :

SERIES: $\mathrm{AX}_{-1} ; \mathrm{AW}_{+1}$

VALUE $\quad 0.924836$

SERIES: $\mathrm{AX}_{-1} ; \mathrm{TUV}, \mathrm{TUV}_{-1}$

STD ERR $\quad 0.034737$

VALUE

0.865578

T-STAT

2. 363818

STD ERR

0.062221

T-STAT

2. 160524

TESTS OF STRONG PPP (EQ. 15) UNDER FLOATING RATE: SUM OF COEFF. $(a+b=1)$ :

DIFF. BETWEEN COEFF. $(a-c=1)$ :

SERIES: $\mathrm{AX}_{-1}, \mathrm{DAX}_{-1} ; \mathrm{AW}_{+1}, \mathrm{DAW}_{+1}$

VALUE $\quad 1.116344$

STD ERR $\quad 0.047402$

T-STAT $\quad 2.454411$

TEST OF WEAK PPP (EQ. 15)

UNDER FIXED RATE: SERIES: $\mathrm{AX}_{-1}, \mathrm{DAX}_{-1}$; TUV, DTUV, TUV

$\begin{array}{ll}\text { VALUE } & 1.141474 \\ \text { STD ERR } & 0.069777 \\ \text { T-STAT } & 2.027516\end{array}$

TEST OF WEAK PPP (EQ. 15)

UNDER FLOATING RATE:

SUM OF COEFF. $(b+c=0)$ :

SUM OF COEFF. $(b+c=0)$ :

SERIES: $\mathrm{AW}_{+1}$; TUV, $\mathrm{TUV}_{-1}$

VALUE $\quad 0.059258$

STD ERR $\quad 0.030592$

T-STAT 1.937049

SERIES: $\mathrm{AW}_{+1}, \mathrm{DAW}_{+1}$; TUV, DTUV, TUV

VALUE $\quad-0.025130$

STD ERR $\quad 0.088724$

T-STAT $\quad-0.283243$

There are three important results in that Table. First, the coefficient of the lagged dependent variable declines sharply (but remains significant) during the floating-rate period, indicating a large reduction in the persistence of the effects of shocks to the exchange rate.

Secondly, the exchange rate became far more responsive to changes in wages; the elasticity of the exchange rate with respect to (future) wages rose from a value now estimated to be 0.205 during the exchange-rate-rule period to 0.816 , the latter value being not significantly different from unity. Indeed, one might interpret the results as indicating that while the authorities were directly managing the exchange rate, they used it as a "brake" on wage increases, but subsequently wages came to dominate the exchange rate. Thirdly, as in the case of wages, the responsiveness of the exchange rate to external prices increased dramatically to a value that 
also is not significantly different from (minus) unity. Clearly the Australian dollar has become very much a "commodity" currency during the floating rate period.

Dumny variables were introduced for the last two quarters of 1988 and the first quarter of 1989 to test for over valuation of the Australian dollar, using the same dummy-variable technique as in Table 3 . The results of this exercise indicate an over valuation (in the goods market) of more than 6 per cent during 1988:4 and over 9 per cent in 1989:1; these estimates are quite consistent with those reported in Table $3 .^{23}$ Behavior of the "Real" Exchange Rate

From equation (11) and the estimates of the $\theta$ coefficients for Australian traded goods reported in Table 2, we have constructed a series for the Australian multilateral "real" exchange rate (MRER); that series is depicted in the Figure referred to earlier and, as can be seen, it not only, exhibits a great deal of variation (particularly so since the early 1980s) but also appears to move counter to external prices (in U.S. dollars). ${ }^{24}$ Unless the movements in the "real" exchange rate can be explained in some plausible fashion, there is little hope of finding any evidence in this context of over or under valuation of the Australian dollar.

${ }^{23}$ Tests of the PPP constraints were also performed on the regression coefficients in Table 5; the results are reported in the second page of that Table. In contrast with the results reported in Table 4, the strong form of the purchasing power parity propositions can be rejected for both the exchange-rate-rule and the floating-rate regimes but the weaker version cannot be rejected for either. The exchange rate appears to have under reacted to changes in wages and external prices during the earlier period and over reacted to those change during the latter period, so that PPP appears to hold well for the period as a whole.

${ }^{24}$ The coefficient of variation of MRER is 0.160 per cent, but it is only about half that of the bilateral "real" exchange rates between the U.S. and Germany (27.5 per cent) and the U.S. and Japan (36.5 per cent). 
Given the behavior of her nominal exchange rate that was reported in the previous subsection, however, it seems plausible that movements in external prices may play an important role in the evolution of the Australian "real" exchange rate. The variables included are a dummy variable (DUM) for the floating rate period, indices of unit values of Australian imports and exports (IUVW and EUVW, respectively) and an internal terms of trade variable (YTT). ${ }^{25}$ The variables IUVW and EUVW are based on the same U.S. dollar unit value indices that were used to construct the TUV variable used in Tables 4 and 5 , but those indices have been converted from U.S. dollars to the "basket" discussed earlier and then deflated by a weighted average of USCB, GCB and NCB (the weights being the same as those in the currency basket) to put those unit values in real terms. The variables DIUVW and DEUVW are simply IUVW and EUVW multiplied by DUM in order to test for a structural change during the floating rate period. Estimation was by maximum likelihood AR1.

The results in Table 6 indicate that both of the real unit value indices are highly significant and that an increase in those unit values leads to a sharp real appreciation. For the "exchange rate rule" period (1972:1 to 1983:4), the elasticity of the "real" exchange rate with respect to the two real unit value variables is -0.607 (with a standard error of $0.067)$; during the floating rate period, that elasticity rose to -1.01 (with a standard error of 0.096). Although the coefficients of DEUVW and DIUVW are not statistically significant, an $F$ test strongly rejects their joint exclusion; moreover, the sum of the coefficients of DIUVW and

\footnotetext{
${ }^{25}$ The variable YTT differs from the TT variable in Table 2 in that it is the $\log$ of the ratio of the Australian GDP deflator to an ABS index of internal prices of traded goods. YTT was used rather than TT as the latter incorporates the variable TUV, which is a simple average of the U.S. dollar indices of import and export unit values.
} 


\section{TABLE 6}

"REAL" EXCHANGE RATE EQUATION FOR AUSTRALIA

$\begin{array}{lccr}\text { DEPENDENT VARIABLE: MRER } & \text { Method: ARI (MAXL) } \\ \text { FROM } 72: 1 & \text { UNTIL 89:1 } \\ \text { OBSERVATIONS } 69 & \text { DEGREES OF FREEDOM } & 61 \\ \text { R**2 } & 0.98937489 & \text { RBAR**2 } & 0.98815562 \\ \text { SSR } & 0.01827482 & \text { SEE } & 0.01730859 \\ \text { DURBIN-WATSON } & 2.32838436 \\ \text { Q(24) } & 12.1478 & \text { SIGNIFICANCE LEVEL } & 0.978192\end{array}$

\begin{tabular}{|c|c|c|c|c|}
\hline VAR I ABLE & LAG & COEFFICIENT & T-STATISTIC & SIGNIF, LEVEL \\
\hline ********** & **** & *************1 & ************ & 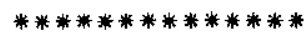 \\
\hline IUVW & 0 & -0.2904481 & -4.030931 & $0.1566964 \mathrm{E}-03$ \\
\hline DIUVW & 0 & -0.3049394 & -1.446261 & 0.1532230 \\
\hline EUVW & 0 & -0.3164684 & -5.270138 & 0.1889844 E-05 \\
\hline DEUVW & 0 & -0.0968216 & -0.593178 & 0.5552548 \\
\hline YTT & 0 & 0.8852935 & 10.374860 & $0.3718992 E-08$ \\
\hline DUM & 0 & 0.8987910 & 3.430495 & 0.1086374 E-02 \\
\hline RHO & & 0.9366088 & 23.608090 & 0.3718988 E-08 \\
\hline
\end{tabular}

Test of Hypothesis That DIUVW And DEUVW Are Irrelevant:

NULL HYPOTHESIS: THE FOLLOWING COEFFICIENTS ARE ZERO Series: DIUVW, DEUVW

$$
F(2,61)=6.212818 \quad \text { SIGNIFICANCE LEVEL } \quad 0.003501099
$$

Tests on Regression Coefficients:

SUM OF COEFF.

Series: DIUVW, DEUVW

VALUE

STD ERR

T-STAT

$-0.4017609$

0.1182171

$-3.3985000$

SUM OF COEFF.

Series: DIUVW, IUVW

$\begin{array}{lr}\text { VALUE } & -0.5953874 \\ \text { STD ERR } & 0.2017186 \\ \text { T-STAT } & -2.9515740\end{array}$
SUM OF COEFF.

Series: IUVW, EUVW

$\begin{array}{lr}\text { VALUE } & -0.6069165 \\ \text { STD ERR } & 0.0670590 \\ \text { T-STAT } & -9.0504840\end{array}$

SUM OF COEFF.

Series: DEUVW, EUVW

$\begin{array}{lr}\text { VALUE } & -0.4132900 \\ \text { STD ERR } & 0.1524009 \\ \text { T-STAT } & -2.7118610\end{array}$

SUM OF COELF".

Series: IUVW, EUVW, DIUVW, DEUVW

$$
\begin{array}{cccc}
\text { VALUE } & -1.0086770 & \text { STD ERR } & 0.0960722 \\
& \text { T-STAT } & -10.49916 &
\end{array}
$$


DEUVW is 0.402 with a standard error of only $0.118 .^{26}$ The internal

terms of trade variable YTT is very important, and its coefficient is not significantly different from unity. As can be seen from the auto correlation coefficient, the estimation is tantamount for first differencing; nevertheless, the degree of explanation is very high. ${ }^{27}$ The results in Table 6 strongly reinforces the view that the Australian dollar is a commodity currency.

Table 7 reports the same regression but with a dummy variable (D884) for the fourth quarter of 1988; the coefficient of that variable is an estimate of the innovation to the residual during that quarter. ${ }^{28}$ The

${ }^{26}$ The variables DIUVW and DEUVW are very highly correlated with one another.

${ }^{27}$ One might argue that high degree of explanation comes about because the YTT variable and the multilateral "real" exchange rate are one and the same; indeed, that is what is suggested by equation (11). However, as the simple correlation between RER and YTT is very low $(-0.133)$, it is clear that either YTT is a poor measure of internal relative prices, or factors other than internal relative prices are at work; indeed, it is only after introducing IUVW and EUVW that the marginal contribution of the YTT variable is significant.

${ }^{28}$ Because we used the AR1 estimation technique, three different methods were used to ensure that the transformed dummy variable had a value of unity in the quarter to which that dummy referred, and zero for all other quarters; the three methods produced very similar results. The first method consisted of introducing only one dummy variable in each equation, but adjusting the length of the time series so that it ended with the quarter to which that dummy referred. The second method consisted of using the entire time series (1972:1 through 1989:1) and introducing all of the dummies in the same equation, but modifying them so that transformed value of the dummy variable was unity for only the quarter to which that dummy referred and zero for all other quarters. For example, D882 had a value of zero until 1988:2 and then the following values:

$\begin{array}{cc}\text { Quarter } & \text { Value of Dummy } \\ 1988: 2 & 1.0 \\ 1988: 3 & \text { Rho } \\ 1988: 4 & \mathrm{Rho}^{2} \\ 1989: 1 & \mathrm{Rho}^{3},\end{array}$

where Rho is the ARI estimate of the auto correlation coefficient 
coefficient of 0884 is -0.049 and it is highly significant, indicating an increase in the over valuation of nearly 5 per cent during 1988:4; this result is quite consistent with the estimates obtained earlier from the price level and nominal exchange rate equations. Dummies for the second and third quarters of 1988 and the first quarter of 1989 were also tried but none were significant, either individually or in jointly. Overall, the results reported in Tables 3,5 , and 7 strongly support the proposition that the Australian dollar was over valued (in the goods market) in late 1988 and early 1989 by from five to nine per cent.

\section{THE CURRENT ACCOUNT VS. THE REAL RATES OF INTEREST AND EXCHANGE}

In this final section, we try to determine if (i) the apparent over valuation of the Australian dollar during late 1988 and early 1989 was due to the capital inflow itself, and (ii) if domestic interest rates are directly influenced by the current account deficit. There are, of course, good theoretical reasons to expect that a significant capital inflow will result in a real appreciation (a decline in the real exchange rate), and this may be what has happened in Australia recently. Moreover, as was pointed out in Section I, much of the foreign borrowing may have a domestic borrowing counterpart, which would tend to drive up interest rates in the local capital market.

The "Real" Exchange Rate and the Capital Inflow Australia has traditionally been a deficit country, and that tendency

reported in Table 7. This method, of course, required an iterative process. The third method used the same definition of the dummy variables as the second and used the entire time series, but only one dummy was introduced into each equation. In all three methods, the coefficient of the dummy variable is an estimate of the innovation to the residual during the quarter in question. The estimate in Table 7 was by the third method. 
TABLE 7

TEST OF OVER VALUATION OF AUSTRALIAN DOLLAR

DEPENDENT VARIABLE: MRER Method: AR1 (MAXL)

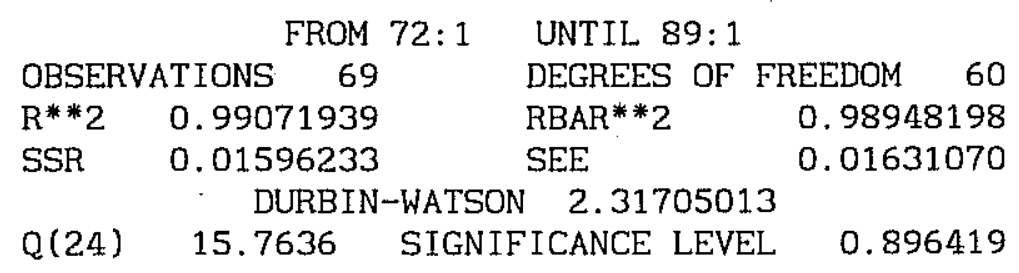

\begin{tabular}{|c|c|c|c|c|}
\hline $\begin{array}{l}\text { VARIABLE } \\
* * * * * * * *\end{array}$ & $\begin{array}{l}\text { LAG } \\
* * *\end{array}$ & $\begin{array}{l}\text { COEFFICIENT } \\
* * * * * * * * * * *\end{array}$ & $\begin{array}{l}\text { T-STATISTIC } \\
* * * * * * * * * * *\end{array}$ & $\begin{array}{l}\text { SIGNIF, LEVEL } \\
* * * * * * * * * * * * * * *\end{array}$ \\
\hline IUVW & 0 & -0.2951984 & -4.313253 & $0.6093512 E-04$ \\
\hline DIUVW & 0 & -0.4608136 & -2.206624 & 0.0311787 \\
\hline EUVW & 0 & -0.3119836 & -5.499722 & $0.8261083 \mathrm{E}-06$ \\
\hline DEUVW & 0 & -0.0127141 & -0.080909 & 0.9357837 \\
\hline YTT & 0 & 0.8737209 & 10.820240 & $0.1024207 \mathrm{E}-14$ \\
\hline DUM & 0 & 1.0599600 & 4.096475 & 0.1276217 E-03 \\
\hline D884 & 0 & -0.0494557 & -2.855949 & 0.0058860 \\
\hline RHO & & 0.9462523 & 27.67645 & 0.0000000 \\
\hline
\end{tabular}

Test of Hypothesis That DIUVW And DEUVW Are Irrelevant: NULL HYPOTHESIS: THE FOLLOWING COEFFICIENTS ARE ZERO Series: DIUVW, DEUVW
$F(2,60)=8.496230$
SIGNIFICANCE LEVEL
$0.5637564 \mathrm{E}-03$

Tests on Regression Coefficients:

SUM OF COEFF.

Series: DIUVW, DEUVW

$$
\begin{array}{lr}
\text { VALUE } & -0.473 \\
\text { STD ERR } & 0.116 \\
\text { T-STAT } & -4.06532 \\
\multicolumn{1}{c}{\text { SUM OF }} & \text { COEFF. }
\end{array}
$$

Series: DIUVW, IUVW

$\begin{array}{lr}\text { VALUE } & -0.7560120 \\ \text { STD ERR } & 0.1996338 \\ \text { T-STAT } & -3.7869940\end{array}$

SUM OF COEFF.

Series: IUVW, EUVW

$$
\begin{array}{lr}
\text { VALUE } & -0.6071820 \\
\text { STD ERR } & 0.0632668 \\
\text { T-STAT } & -9.5971670
\end{array}
$$

SUM OF COEFF.

Series: DEUVW, EUVW

$$
\begin{array}{lr}
\text { VALUE } & -0.3246977 \\
\text { STD ERR } & 0.1471156 \\
\text { T-STAT } & -2.2070910
\end{array}
$$

SUM OF COEFF.

Series: IUVW, EUVW, DIUVW, DEUVW

$$
\begin{array}{cccc}
\text { VALUE } & -1.080710 & \text { STD ERR } & 0.0959295 \\
\text { T-STAT } & -11.26566 &
\end{array}
$$


has accelerated in the course of the 1980s; indeed, during that decade, there has not been a single quarter in which the current account has been in surplus. As most of Australia's external debt has been incurred since 1981 , we shall focus our attention on the period of the 1980s. ${ }^{29}$

The first approach was the use of causality tests to determine in past current account deficits seems to "cause" movements in the "real" exchange rate. The key variable is the current account balance (CAB), which is defined to be positive when there is a deficit, and is expressed as a percentage of the Australian Gross Domestic Product. ${ }^{30}$ For the period 1981:1 to 1989:1, Granger causality tests in which MRER was the dependent variable and lagged MRER and contemporary as well as lagged CAB were independent variables conclusively reject the hypothesis that the current account deficit "causes" the real exchange rate; these tests were conducted using both the raw and the deseasonalized series for $C A B$, and for lags of four, six, and eight quarters. The level of significance of current and lagged $\mathrm{CAB}$ in the six $\mathrm{F}$ tests ranged from 0.34 to 0.70 .

As a further test, we introduced the current account deficit variable into the "real" exchange rate equation reported in Table 6. As the data series on the current account begins with 1981:1, it covers mainly the floating exchange rate period. A preliminary $F$ test indicated that the dummy variables for the 1981:1 to 1989:1 period were not collectively

${ }^{29}$ In mid-1981, Australia's external debt was only A 8.5 billion; by the end of 1989, it was over A 100 billion.

${ }^{30}$ The data on the current account were obtained from the IFS, which reports them in U.S. dollars; the data were converted to Australian dollars using the quarterly average exchange rate. The raw data exhibit a very strong seasonal which was removed by a regression with seasonal dummy variables. Unless indicated otherwise, the deseasonalized version of $C A B$ was used in all tests and regressions reported below. 
significant, so those variables were not included in the regression. ${ }^{31}$ The estimated equation is reported in Table 8; as one can see, the $C A B$ variable is significant only when it is lagged two quarters, and then it has the wrong sign. Taken together, the current lagged $C A B$ variables were only marginally significant (the $F$ test on their exclusion has a significance of only 0.06 ) and the sum of the three coefficients is not significantly different from zero. We reject, then, the hypothesis that the current account deficit has systematically influenced the multilateral "real" exchange rate, and hence the proposition that the apparent over valuation of the Australian dollar in late 1988 and early 1989 came about because of the capital inflow.

Domestic Interest Rates and the Current Account Deficit

Ad hoc regression analysis was used to determine the relationship, if any, between the current account deficit and the domestic rate of interest. No speciflc model was developed; rather, we simply experimented with variables that frequently are thought to influence interest rates: the rate of inflation, external interest rates, the rate of devaluation, and the current account balance. Neither the external rate of interest (measured by $L I B O R$ ) nor the devaluation rate were significant when regressed on the domestic rate of interest; moreover, the external rate of interest corrected for the devaluation rate was also insignificant. ${ }^{32}$ We are left,

${ }^{31}$ The significance of the $F$ test on the exclusion of all three dummy variables was 0.13 .

The variable that was constructed took the form:

$$
\text { LIBORADJ }_{t}=\left(1.0+\text { LIBOR }_{t}\right) \cdot\left(1.0+\mathrm{DEV}_{t}\right)-1.0 \text {, }
$$

where LIBOR $t$ of the three-month London InterBank offer Rate (on an annual basis) on the U.S. dollar for quarter $t$, and $D E V_{t}$ is the devaluation from quarter $t-1$ to quarter $t+1$, again expressed as an annual rate. 
TABLE 8

EFFECT ON THE "REAL" EXCHANGE OF THE CURRENT ACCOUNT DEFICIT

DEPENDENT VARIABLE: MRER METHOD: OLS

FROM $81: 4$ UNTIL $89: 1$

\begin{tabular}{|c|c|c|c|}
\hline OBSEI & 30 & DEGREES OF & FREEDOM \\
\hline $\mathrm{R}^{* * 2}$ & 0.99693590 & $\mathrm{RBAR}^{* * 2}$ & 0.9961365 \\
\hline סח & 8328 & SEE & 0.010179 \\
\hline & & & \\
\hline
\end{tabular}

\begin{tabular}{|c|c|c|c|c|}
\hline $\begin{array}{l}\text { VARIABLE } \\
* * * * * * * *\end{array}$ & $\begin{array}{l}\text { LAG } \\
* * *\end{array}$ & $\begin{array}{l}\text { COEFFICIENT } \\
* * * * * * * * * * *\end{array}$ & $\begin{array}{l}\text { T-STATISTIC } \\
* * * * * * * * * * * *\end{array}$ & $\begin{array}{l}\text { SIGNIF, LEVEL } \\
* * * * * * * * * * * * * * *\end{array}$ \\
\hline IUVW & 0 & -0.7631090 & -9.076069 & $0.8326671 \mathrm{E}-\mathrm{C}$ \\
\hline EUVW & 0 & -0.3057696 & -5.444699 & $0.1558909 \mathrm{E}-\mathrm{C}$ \\
\hline YTT & 0 & 0.9600605 & 14.440460 & $0.3719494 \mathrm{E}-\mathrm{C}$ \\
\hline $\mathrm{CAB}$ & 0 & -0.0023330 & -0.990302 & 0.3323313 \\
\hline $\mathrm{CAB}$ & 1 & -0.0018884 & -0.647757 & 0.5237563 \\
\hline $\mathrm{CAB}$ & 2 & 0.0067671 & 2.565029 & 0.0173102 \\
\hline
\end{tabular}

TEST OF HYPOTHESIS THAT CONTEMPORARY AND

AND LAGGED CAB ARE IRRELEVANT:

NULL. HYPOTHESIS: THE FOLLOWING COEFFICIENTS ARE ZERO:

SERIES: $\mathrm{CAB}, \mathrm{CAB}_{-1}, \mathrm{CAB}_{-2}$

$F(3,23)=2.873795$, SIGNIFICANCE LEVEL: 0.0582318

TESTS ON REGRESSION COEFFICIENTS:

SUM OF COEFF.

SERIES: $\mathrm{CAB}, \mathrm{CAB}_{-1}, \mathrm{CAB}_{-2}$

VALUE

STD ERR

T-STAT
0.002746
0.002503
1.017001

SUM OF COEFF.

SERIES: IUVW, EUVW

$\begin{array}{lr}\text { VALUE } & -1.068879 \\ \text { STD ERR } & 0.030733 \\ \text { T-STAT } & -34.779880\end{array}$

then, with the rate of inflation and the current account balance.

It was assumed that if the current account balance were to influence the interest rate, that influence would be most clearly registered on the real rate of interest. It was also assumed that changes in the rate of inflation might well affect the real rate of interest in the short run, but not necessarily in the long run. The equation that was estimated, then, took the following general form:

$$
\begin{aligned}
\operatorname{RINT}_{t} & =\operatorname{CONSTANT}+\alpha \cdot \operatorname{RINT}_{t-1}+\beta \cdot \operatorname{RINT}_{t-2}+\gamma \cdot \operatorname{INF}_{t}+\delta \cdot \operatorname{INF}_{t-1} \\
& +\rho \cdot \operatorname{INF}_{t-2}+z_{1}
\end{aligned}
$$


where RINT is the real rate of interest, INF the inflation rate, and $Z$ a linear combination of all other relevant variables. This specification permits (unexpected?) inflation to have a short run impact on the real rate of interest $(\gamma \neq 0)$, but if the sum of $\gamma, \delta$, and $\rho$ is close to zero there is no significant long run effect. Moreover, if the sum of $\alpha$ and $\beta$ are close to zero, the short and long run coefficients of each of the remaining variables will be much the same.

The quarterly nominal interest rate that was used is a monthly average of "authorized dealer" money market rates as reported in the Bulletin of the Reserve Bank of Australia, and is on an annual basis. The inflation rate for quarter $t$ is the rate of change in the ACPI from quarter $t-1$ to quarter $t+1$, again expressed on an annual basis. The interest rate, inflation, and current account deficit data are all in percentage terms. ${ }^{33}$ The results are reported in Table 9. The first block of coefficients refers to unrestricted estimates, and the second block contains the estimates made subject to the restrictions that $(\alpha+\beta)=(\gamma+\delta+\rho)=0$. As the $F$ test on the simultaneous imposition of the two restrictions had a significance level of 0.29 , the restricted estimates are quite acceptable and we confine our attention to them alone. ${ }^{34}$

The results indicate that a transitory increase in the rate in the rate of inflation immediately and substantially depresses the real rate of interest-even though that real rate is based on a very short term nominal rate. Subsequently, the real rate rises to well above the level it would have reached without the transitory shock to the inflation rate, and then

\footnotetext{
${ }^{33}$ The real interest rate, RINT, was computed as $\left(\operatorname{INT}_{t}-\mathrm{INF}_{t}\right) /\left(1.0+\mathrm{INF}_{t}\right)$, where INT is the nominal rate of interest.

${ }^{34}$ The second lag on the inflation rate was not significant.
} 
TABLE 9

EFFECT OF THE CURRENT ACCOUNT BALANCE ON REAL INTEREST RATES

$\begin{array}{lccr}\text { DEPENDENT VARIABLE: RINT } & \text { METHOD: FILTERED OLS } \\ \text { FROM } 82: 3 & \text { UNTIL. 89:1 } \\ \text { OBSERVATIONS } 27 & \text { DEGREES OF } & \text { FREEDOM r } & 20 \\ \mathrm{R}^{*} 2 & 0.85838928 & \text { RBAR**2 } & 0.81590607 \\ \text { SSR } & 28.50666200 & \text { SEE } & 1.19387310 \\ \text { DURBIN-WATSON } & 2.32570783 \\ \text { Q(24) } & 6.11018 & \text { SIGNIFICANCE LEVEL } & 0.942051\end{array}$

\begin{tabular}{|c|c|c|c|c|}
\hline $\begin{array}{l}\text { VARIABLE } \\
* * * * * * * *\end{array}$ & $\begin{array}{l}\text { LAG } \\
* * * *\end{array}$ & $\begin{array}{l}\text { COEFFICIENT } \\
* * * * * * * * * * *\end{array}$ & $\begin{array}{l}\mathrm{T}-\text { STATISTIC } \\
* * * * * * * * * * *\end{array}$ & 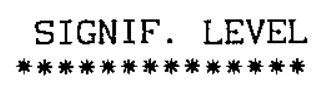 \\
\hline RINT & 1 & 0.4635853 & 2.822408 & 0.0105219 \\
\hline RINT & 2 & -0.4636142 & -3.246633 & 0.0040417 \\
\hline INF & 0 & -0.9963049 & -4.315224 & 0.3366757 E-03 \\
\hline INF & 1 & 0.7346364 & 3.907439 & $0.8734569 \mathrm{E}-03$ \\
\hline $\mathrm{CAB}$ & 1 & 1.237632 & 3.588321 & 0.0018375 \\
\hline SERVICE & 0 & 2.629327 & 3.488228 & 0.0023174 \\
\hline
\end{tabular}

Tests on Regression Coefficients:

SUM OF COEFF.

$\begin{array}{lr}\text { Series: } & \text { RINT }_{-1}, \text { RINT }_{-2} \\ \text { VALUE } & -0.289069 \text { E-04 } \\ \text { STD ERR } & 0.173981 \\ \text { T-STAT } & -0.166150 \text { E-03 }\end{array}$

SUM OF COEFF.

Series: $\mathrm{INF}, \mathrm{INF}_{-1}$

$\begin{array}{lr}\text { VALUE } & -0.2616686 \\ \text { STD ERR } & 0.1656549 \\ \text { T-STAT } & -1.5796000\end{array}$

TEST ON RESTRICTIONS ON RINT AND INF

$$
F(2,20)=1.312021 \quad \text { SIGNIFICANCE LEVEL } \quad .2914727
$$

RESTRICTED ESTIMATES

\begin{tabular}{|c|c|c|c|c|}
\hline $\mathrm{R}^{* * 2}$ & 0.83980966 & & $\mathrm{RBAR}^{* * 2}$ & 0.81068414 \\
\hline SSR & 32.24679700 & & SEE & 1.21068414 \\
\hline & DURBIN & WATSON & 1.98829023 & \\
\hline$(24$ & 4.45848 & SIGNIFI & CANCE LEVEL & 0.98526 \\
\hline
\end{tabular}

\begin{tabular}{|c|c|c|c|c|}
\hline $\begin{array}{l}\text { VARIABLE } \\
* * * * * * * * *\end{array}$ & $\begin{array}{l}\text { LAG } \\
* * *\end{array}$ & $\begin{array}{l}\text { COEFFICIENT } \\
* * * * * * * * * * * *\end{array}$ & $\begin{array}{l}\mathrm{T} \text {-STATISTIC } \\
\text { * }^{*} * * * * * * * * * * *\end{array}$ & 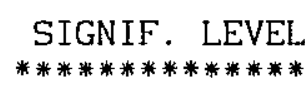 \\
\hline RINT & 1 & 0.5373120 & 4.528662 & 0.1658487 E-03 \\
\hline RINT & 2 & -0.5373120 & -4.528662 & $0.1658487 \mathrm{E}-03$ \\
\hline INF & 0 & -0.7770196 & -4.127251 & $0.4421768 \mathrm{E}-03$ \\
\hline INF & 1 & 0.7770196 & 4.127251 & $0.4421768 E-03$ \\
\hline $\mathrm{CAB}$ & 1 & 0.9716642 & 4.594538 & $0.1412164 \mathrm{E}-03$ \\
\hline SERVICE & 0 & 3.2704600 & 5.458335 & 0.1749727 E-04 \\
\hline
\end{tabular}


experiences damped oscillations; there is no lasting effect as the coefficient of RINT $_{t-2}$ is not significantly different from the (absolute value of the) coefficient of $\mathrm{RINT}_{t-1}{ }^{35}$ More significantly, a rise in the current account deficit by one percentage point of GDP increases the real rate of interest by about one percentage point. ${ }^{36}$

One additional variable, SERVICE, was introduced; this variable is a rough estimate the quarterly interest service on the external debt as a percentage of GDP. ${ }^{37}$ The reason for introducing this variable is the following. Suppose, for the moment, that the current account is in balance at given point in time; then the surplus in the trade account will be roughly equal to the interest service on the external debt. Consequently, the greater is the that interest service, the greater is the requisite surplus in the trade account and hence the smaller is domestic expenditure on goods and services (exclusive of interest payments on the external debt) relative to domestic output. Presumably, an increase in the domestic real rate of interest is required to bring about that reduction in expenditure. The results in Table 9 appear to bear out that argument, as the coefficient of SERVICE is both positive and highly significant.

\footnotetext{
${ }^{35}$ The implicit difference equation is nonexplosive for the unrestricted estimate; the same was true for the equations reflecting all possible combinations of restrictions.

${ }^{36}$ With only contemporary $\mathrm{CAB}$ in the equation, the coefficient is about the same as that of the lagged value; with both the contemporary and lagged values of $C A B$ in the equation, the sum of the coefficients was about the same as that in Table 9, but the coefficient of contemporary $C A B$ was not significant.

${ }^{37}$ The variable SERVICE is defined as LIBOR (at a quarterly rather than an annual rate) times the accumulated nominal current account deficit in U.S. dollars since 1981:1, which is then converted to Australian dollars and expressed as a percentage of quarterly GDP. This variable assumes that the interest rate on foreign debt is LIBOR and it ignores all debt incurred ргior to $1981: 1$; the latter deficiency, of course, affects only the constant term.
} 
Neither the current account deficit nor debt service, however, can explain the increase in the real interest rate that occurred in late 1988 and early 1989. For the entire period (1981:1 to 1989:1), the average current account deficit was 4.79 per cent of GDP and the eight quarters ending with 1988:2, that average was 4.17 per cent. During 1988:4 and 1989:1, the current account deficit increased by only one percentage point-to 5.24 per cent of GDP. That increase, even together with the small increase in interest service, can explain but a small fraction of the increase in the real rate of interest during 1988:4 and 1989:1. One concludes, then, that the current account deficit can hardly be the explanation for the high level of real rates of interest that prevail in Australia.

\section{Main Conclusions}

The objective of this research was straightforward: to search for evidence that the sharp increase in the real rate of interest in Australia during late 1988 and early 1989 was due to a growing "over valuation" of the Australian dollar. To do so, we first developed a model for the price level of Australia, and that model performed extremely well empirically. The results indicate that, despite her splendid geographic isolation, Australia is not at all insulated from shocks arising from external inflation and movements in third-country exchange rates. Indeed, it was found that external prices (together with the Australian exchange rate) had an influence at least as great as that of domestic wages on the Australian price level.

This is not to say, however, that the effects of foreign inflation and fluctuations in third-country exchange rates impact directly on the Australian price level; to the contrary, those effects are neutralized almost immediately by the mechanics of the Australian exchange rate, 
particularly so since the exchange rate was floated in late 1983 . There is strong evidence that, for the period as a whole (1972: 1989:1), purchasing power parity held very tightly; however, the evidence does not support that proposition for either of the two sub periods (1972:1 to 1983:4 and 1984:1 to $1989: 1$ ).

The study did find evidence that the Australian dollar was becoming increasing over valued in the goods markets during the second half of 1988 , and early 1989. Three separate approaches were used in this endeavor, and the results suggest an over valuation of from 5 to as much as 9 percent by the first quarter of 1989 . This apparent over valuation provides a plausible explanation for the high level of the domestic real rate of interest during 1989.

The study also investigated the relationship between the current account of the balance of payments, on the one hand, and the multilateral "real" exchange rate and the real rate of interest, on the other. Evidence consistent with the proposition that a current account deficit leads a decline in the "real" exchange rate was not found. There is strong evidence, however, that both interest payments on external debt and a deficit in the current account tend to increase the real rate of interest. These considerations are, however, able to explain only a small part of the increase in the real rate of interest that has actually occurred. It appears quite likely, then, that the rise in interest rates during late 1988 and early 1989 was due to anticipation of a significant real depreciation of the Australian dollar. 


\section{APPENDIX}

\section{The Currency Basket}

The currency basket is defined by equation (A1):

$$
e_{U S}=x_{U S}+\left(x_{G} \cdot e_{U S, G}\right)+\left(x_{N} \cdot e_{U S, N}\right) \text {. }
$$

where $e_{j}$ is the arithmetic price of the basket in terms of currency $j$, $e_{i, j}$ is the arithmetic price of currency $j$ in terms of currency $i$, and $x_{j}$ is the number of units of currency $j$ in the basket. The share of the each currency in the basket is designated by $\gamma_{j}$ :

$$
\begin{aligned}
& \gamma_{U S} \equiv x_{U S} / e_{U S^{\prime}} \\
& \gamma_{G} \equiv\left(e_{U S, G} \cdot x_{G}\right) / e_{U S^{\prime}} \\
& \gamma_{N} \equiv\left(e_{U S, N} \cdot x_{N}\right) / e_{U S} .
\end{aligned}
$$

Noting that $e_{i, j}=e_{i} / e_{j}$, we can rewrite the $D M$ and yen shares as:

$$
\begin{aligned}
& \gamma_{G}=x_{G} / e_{C}, \\
& \gamma_{N}=x_{N} / e_{N} .
\end{aligned}
$$

Letting $E_{j}$ and $P_{j b}^{*}$ be, respectively, the natural logarithms of $e_{j}$ and of the price level in country $j$ measured in terms of the basket, the following relationships are readily verified:

$$
\begin{aligned}
& E_{i j}=E_{i}-E_{j} \\
& P_{j}^{*}=P_{j b}^{*}+E_{j} .
\end{aligned}
$$

These relationships can be used to transform text equation (13) into:

$$
P_{A}^{*}=\beta_{O}+\beta_{1} \cdot P_{A}^{H}+\beta_{A} \cdot E_{A}+\beta_{U S} \cdot P_{U S, b}^{*}+\beta_{C} \cdot P_{G, b}^{*}+\beta_{N} \cdot P_{N, b}^{*} \cdot
$$

While the coefficients of text equation (13) and equation (A3) above are identical in a deterministic context, the properties of the estimators of the coefficients of the two equations may be quite different.

We wish to chose the composition of the basket such that the "weight" of each currency in that basket reflects the relative influence on the Australian price level of that currency as indicated by the estimates of 
the $\beta_{j}$ coefficients of equation (A3). To evaluate that relative influence, it is convenient to modify that equation somewhat; in the case of say, Germany, $E_{G}=E_{G, U S}+E_{U S}$ and $P_{G, b}^{*}=P_{G}^{*}-E_{G}$, so equation (A3) can be rewritten as:

$$
\begin{aligned}
P_{A}^{*} & =\beta_{O}+\beta_{1} \cdot P_{A}^{H}+\beta_{A} \cdot E_{A, U S}+\beta \cdot E_{U S}-\beta_{G} \cdot E_{G, U S}-\beta_{N} \cdot E_{N, U S}+\beta_{U S} \cdot P_{U S}^{*} \\
& +\beta_{G} \cdot P_{G}^{*}+\beta_{N} \cdot P_{N},
\end{aligned}
$$

where:

$$
\beta \equiv \beta_{A}-\beta_{U S}-\beta_{G}-\beta_{N} .
$$

The impact on the Australian price level of a nominal depreciation of the Australian dollar is:

$$
\partial \mathrm{P}_{\mathrm{A}}^{*} / \partial \mathrm{E}_{\mathrm{A}, \mathrm{US}}=\beta_{\mathrm{A}} \text {. }
$$

The effect of a real depreciation of the DM against the U.S. dollar is:

$$
\partial P_{A}^{*} / \partial E_{C, U S}=\beta \cdot\left(\partial E_{U S} / \partial E_{G, U S}\right)-\beta_{C} \text {. }
$$

Holding the $x_{j}$ (but not the $\gamma_{j}$ ) constant, it follows from (A1) and (A2b): that $a E_{U S} / \partial E_{G, U S}=-\gamma_{G} ;$ therefore:

$$
\partial P_{A}^{*} / \partial E_{G, U S}=-\left(\beta \cdot \gamma_{G}+\beta_{G}\right) \text {. }
$$

Similarly, the effect of a real depreciation of the Yen is:

$$
\partial \mathrm{P}_{\mathrm{A}}^{*} / \partial \mathrm{E}_{\mathrm{N}, \mathrm{US}}=-\left(\beta \cdot \gamma_{\mathrm{N}}+\beta_{\mathrm{N}}\right) \text {. }
$$

Finally, the effect on the Australian price level of a real depreciation of the U.S. dollar is:

$$
\begin{aligned}
\partial P_{A}^{*} / \partial E_{U S, G}+ & \partial P_{A}^{*} / \partial E_{U S, N}+\partial P_{A}^{*} / \partial E_{U S, A} \\
& =-\partial P_{A}^{*} / \partial E_{G, U S}-\partial P_{A}^{*} / \partial E_{N, U S}-\partial P_{A}^{*} / \partial E_{A, U S} \\
& =\beta \cdot\left(\gamma_{G}+\gamma_{N}\right)+\beta_{G}+\beta_{N}-\beta_{A} \\
& =\beta \cdot\left(1-\gamma_{U S}\right)+\beta_{C}+\beta_{N}-\beta_{A} \\
& =-\left(\beta \cdot \gamma_{U S}+\beta_{U S}\right) .
\end{aligned}
$$

Setting the relative share (i.e, $\gamma_{1} / \gamma_{u S}$ ) of each currency in the 
basket equal to the relative impacts of each of the three currencies on the Australian price level, using the constraint that the shares sum to unity, and simplifying, we obtain:

$$
\begin{aligned}
& \gamma_{U S}=\beta_{U S} /\left(\beta_{U S}+\beta_{G}+\beta_{N}\right), \\
& \gamma_{G}=\beta_{G} /\left(\beta_{U S}+\beta_{G}+\beta_{N}\right), \\
& \gamma_{N}=\beta_{N} /\left(\beta_{U S}+\beta_{G}+\beta_{N}\right) .
\end{aligned}
$$

We solve for the relative amount of each currency in the basket by combining equations $(\mathrm{A} 2 \cdot)$ and $(\mathrm{A} 4 \cdot)$ :

$$
\begin{aligned}
& x_{G} / x_{U S}=e_{G, U S} \cdot\left(\beta_{G} / \beta_{U S}\right), \\
& x_{N} / x_{U S}=e_{N, U S} \cdot\left(\beta_{N} / \beta_{U S}\right) .
\end{aligned}
$$

As the overall "size" of the basket is arbitrary, we can arbitrarily choose the value for $x_{U S}$. Thus equations (A5) and (A6) determine the amounts of each currency in the basket as a function of exchange rates and the estimates of the $\beta_{j}$ parameters of equation (A3).

Unfortunately, fixing the shares according to equations (A4*) causes equation (A3) to degenerate to text equation (13). To demonstrate this, consider the following ratio of the shares as defined in equations (A2.):

$$
\gamma_{\mathrm{US}} / \gamma_{\mathrm{N}}=\mathrm{e}_{\mathrm{N}, \mathrm{US}} \cdot\left(\mathrm{x}_{\mathrm{US}} / \mathrm{x}_{\mathrm{N}}\right) \text {. }
$$

As we can fix one of the $x_{\text {, }}$ arbitrarily, set $x_{U S}=N$ (where $N$ is any positive real number):

$$
\mathrm{x}_{\mathrm{N}}=\left(\mathrm{N} \cdot \mathrm{e}_{\mathrm{N}, U S}\right) \cdot\left(\gamma_{\mathrm{N}} / \gamma_{\mathrm{US}}\right),
$$

and similarly:

$$
\mathrm{x}_{\mathrm{G}}=\left(\mathrm{N} \cdot \mathrm{e}_{\mathrm{G}, \mathrm{US}}\right) \cdot\left(\gamma_{\mathrm{G}} / \gamma_{\mathrm{US}}\right) .
$$

Inserting these values into equation (A1) and simplifyirg, we obtain:

$$
\mathrm{e}_{\text {us }}=\mathrm{N} / \gamma_{\text {us }} .
$$

Thus by fixing the shares and $x_{U S}=N$, the U.S. dollar price of the basket becomes invariant with respect to the value of the dollar in terms of other currencies. Moreover, the DM and Yen prices of the basket are proportional 
to the DM and Yen prices of the U.S. dollar:

$$
\mathrm{e}_{\mathrm{G}}=\mathrm{e}_{\mathrm{G}, \mathrm{US}} \cdot\left(\mathrm{N} / \mathrm{\gamma}_{\mathrm{US}}\right) \text {, }
$$

and: $\quad e_{N}=e_{N, U S} \cdot\left(N / \gamma_{U S}\right)$.

Fixing the shares, then, defeats our purpose as it results in equation (A3) having econometric properties similar to those of text equation (13).

One simple solution is to fix the amounts of each currency in the basket, which permits the shares vary with exchange rates. To do that, we merely replace the actual exchange rates in equations (A5) and (A6) with the period averages $\left(\bar{e}_{1, j}\right)$ of those rates:

$$
\begin{aligned}
& x_{G}=x_{U S} \cdot \vec{e}_{G, U S} \cdot\left(\beta_{G} / \beta_{U S}\right), \\
& x_{N}=x_{U S} \cdot \bar{e}_{N, U S} \cdot\left(\beta_{N} / \beta_{U S}\right) .
\end{aligned}
$$

As the size of the basket is arbitrary, we might choose $x_{u s}$ as follows:

$$
x_{U S}=\beta_{U S} /\left(\beta_{U S}+\beta_{G}+\beta_{N}\right) \text {. }
$$

Accordingly, the values of $x_{C}$ and $x_{N}$ are given by equations $\left(A 5^{\prime}\right)$ and (A6'):

$$
\begin{aligned}
& x_{G}=\left(\bar{e}_{G, U S} \cdot \beta_{G}\right) /\left(\beta_{U S}+\beta_{C}+\beta_{N}\right), \\
& x_{N}=\left(\bar{e}_{N, U S} \cdot \beta_{N}\right) /\left(\beta_{U S}+\beta_{G}+\beta_{N}\right) .
\end{aligned}
$$

